\title{
Collaborative Writing with Web 2.0 Technologies: Education Students' Perceptions
}

\author{
Cornelia Brodahl, Said Hadjerrouit, and Nils Kristian Hansen \\ University of Agder, Kristiansand, Norway
}

\section{Cornelia.Brodahl@uia.no Said.Hadjerrouit@uia.no \\ Nils.K.Hansen@uia.no}

\section{Executive Summary}

Web 2.0 technologies are becoming popular in teaching and learning environments. Among them several online collaborative writing tools, like wikis and blogs, have been integrated into educational settings. Research has been carried out on a wide range of subjects related to wikis, while other, comparable tools like Google Docs and EtherPad remain largely unexplored in the literature. This work presents a case study investigating education students' perceptions of collaborative writing using Google Docs and EtherPad. Both tools provide opportunity for multiple users to work on the same document simultaneously, have a separate space for written metacommunication, and are promoted by software designers to be fairly intuitive to adopt without prior training. The work investigates if perceptions depend on factors such as gender, age, digital competence, interest in digital tools, educational settings, and choice of writing tool, and examines if the tools are easy to use and effective in group work. This paper focuses on quantitative results of survey questionnaires. Further qualitative analysis will be presented in a later paper.

The theoretical framework is drawn from two learning theories, the social-constructivist learning theory and the community of practice, and their relationships to collaborative tools. Related research literature is characterized by a number of issues: positive elements of use, advantages of using Web 2.0 technologies, critical issues regarding the pedagogical value of Web 2.0, and the role of the teacher in using these technologies.

The case study participants were 201 education students who just began their four-year initial teacher education at two study programs with a total of six classes at the university Teacher Education Unit. They were assigned a collaborative writing task and asked to take an on-line survey on completion. When the survey closed, a total of 166 students $(83.6 \%)$ had participated. The results were analyzed based on frequency distributions.

The hypothesis that students with high digital competence and a positive attitude towards digital tools are more positive than average seems to be confirmed. Also gender does not play any particular role. As for younger students being more positive than older, the population of older stu-

Material published as part of this publication, either on-line or in print, is copyrighted by the Informing Science Institute. Permission to make digital or paper copy of part or all of these works for personal or classroom use is granted without fee provided that the copies are not made or distributed for profit or commercial advantage AND that copies 1) bear this notice in full and 2) give the full citation on the first page. It is permissible to abstract these works so long as credit is given. To copy in all other cases or to republish or to post on a server or to redistribute to lists requires specific permission and payment of a fee. Contact HPublisher@InformingScience.orgH to request redistribution permission. dents was so low that no conclusion can be drawn. The work does not validate that EtherPad users are more positive than Google Docs users, but this may be explained by EtherPad being unavailable for some time during the students' collaborative writing period.

Furthermore only $13.9 \%$ of the students were motivated to use the tools for collaboration, and only a minority of the 
students $(15.7 \%)$ reported that the quality of collaboration in the group increased with use of the tools. Likewise, the tools did not work as expected for a majority of the students (70.5\%). Fortyseven percent of the students liked to comment and edit others contributions to group work.

Although the results cannot be generalized to a larger group of students, and no definite conclusions can be drawn from the questionnaires about the usefulness and effectiveness of Google Docs and EtherPad for collaborative writing, the results cannot be underestimated since some results are consistent with the research literature.

Future research consists of the qualitative evaluation of the students' comments to open endedquestions in the questionnaire, the students' collaborative essay papers, and their contributions to group work. It may also be important to examine the extent and quality of utilization of the tools for collaborative writing. Triangulation of the data collected may shed light on how they really perceived the effectiveness of Google Docs and EtherPad to support collaborative writing among students.

Keywords: Collaborative writing, collaborative tools, EtherPad, Google Docs, Web 2.0 technologies.

\section{Introduction}

Low cost, ubiquity, accessibility and ease of use are all potential affordances making Web 2.0 technologies more attractive than traditional software in teaching and learning environments (Ajjan \& Hartshorne, 2008). During the last few years, the use of several online collaborative writing tools, e.g., blogs and wikis, has been integrated into educational settings. The advantages of wikis for a variety of different uses and their inclusion in learning processes have been broadly studied and documented in classrooms, distance and blended learning, as have the potential pitfalls and critical issues associated with their use. In higher education settings, research has been carried out on a wide range of subjects related to wikis, including issues such as didactic and organizational arrangements for learning, design of open learning environments, and knowledge production (Baltzersen, 2010; Bonk, Lee, Kim \& Lin, 2009; Karasavvidis, 2010; Kasemvilas \& Olfman, 2009; Pusey \& Meiselwits, 2009; Rice, 2009; Su \& Beaumont, 2010; Trentin, 2009). However the use of Google Docs (2008) and EtherPad (2008), being collaborative writing tools relatively comparable to wikis, remains largely unexplored in the literature (Chu, Kennedy, \& Mak, 2009). Although, Garner (2010) provides a discussion of how technologies like Google Docs can support the personal knowledge management.

Google Docs (GD) and EtherPad (EP) are tools promoted by software designers to be fairly intuitive to adopt for anyone accustomed to a word processor like Microsoft Word or Open Office Writer. Yet the fact remains that it is difficult to predict how students will behave in a real educational setting. Taking the complexity of learning processes into consideration, the educational use of GD and EP raises a number of questions. How important is the students' digital literacy and previous knowledge in ICT in such situations? What role do parameters such as age, gender, and number of collaborators play in the collaboration and learning process? Are GD and EP potentially powerful tools supporting collaborative learning and encouraging the students to collaborate? And, is introducing the tools possible without teaching them in detail? Clearly, there is a need to explore these issues experimentally.

This case study investigates beginner education students' perceptions of collaborative Web 2.0 tools to support academic work. The goal is to enrich the empirical results in this domain by evaluating the perceived effectiveness of GD and EP as online collaborative tools. The investigation is carried out in collaboration with teacher educators in a setting with groups of undergraduate education students using the tools to collectively write a reflective essay paper. 
The case study is structured according to three categories: subject, object, and approach. The subjects of the study are education students. The object of the study is the use of collaborative writing tools in teacher education. The approach is exploratory, considering questions posed below, and theory-building.

The paper is structured as follows. First, the research question is presented. Second, the theoretical framework is described. Third, the collaborative tools GD and EP are outlined. This is followed by the methodology of the work. Then, the results are presented and analyzed. Finally, some remarks and future work conclude the article.

\section{Research Questions and Hypotheses}

This work examines education students' perceptions of collaborative writing by means of the collaborative tools GD and EP. The investigation is situated in teacher education and an established partnership between the Faculty of Technology and Sciences and two studies, associated with three classes each and in two different cities.

Accordingly, the research questions are:

- How do students perceive collaborative writing with GD and EP?

- Do perceptions vary depending on factors like gender, age, digital competence, interest in and opinion on importance of digital tools, educational settings and choice of writing tool?

- Are the tools easy to use and effective in group work?

The research hypotheses are:

- Students with high digital competence and a positive attitude towards digital tools are more positive than average.

- Younger students are more positive than older.

- Gender does not play any particular role.

- EP-users are more positive than GD-users as EP is easier to use.

\section{Theoretical Framework}

The proposed theoretical framework serving as a foundation for this work is drawn from two learning theories - the social-constructivist learning theory and the community of practice - and their reciprocal relationship to collaborative tools. The framework identifies two major elements and how they might relate to each other: firstly, learning theories that help to understand the very nature of collaborative learning in terms of learner engagement, group discussion, collaboration, participation in communities of practice, language and culture, and negotiation of meaning; secondly, collaborative tools that serve as means of communication for collaborative learning activities where group members use various techniques to write collaboratively, share their knowledge, post information, and discuss issues of common interest. The framework specifies collaborative learning processes and collaborative tools in a dialectical relationship. The quality of collaboration depends both on students' prerequisite knowledge in terms of collaborative skills, on the one hand, and the potential capabilities of the tools in supporting students' collaborative learning in terms of user-friendliness and effectiveness, on the other hand. Collaboration presupposes a trouble-free interaction with the tool in order for the students to work collaboratively. 
The purpose of this framework is to guide the implementation and evaluation of collaborative writing with GD and EP. The framework addresses both technical and pedagogical issues of collaborative writing. It provides support to investigate the research questions, analyze and interpret the results, and draw some conclusions for collaborative writing. The framework is an attempt to make meaningful links between the collaborative tools GD and EP and collaborative learning, based on current learning theories. The effectiveness of the framework in practice will depend on the strength of the links between the learning theories and the collaborative tools being used.

\section{Socio-Constructivist Learning Theory}

Theories of collaborative learning are based on the socio-constructivist theory that knowledge is socially produced by communities of people and that individuals can gain knowledge if they join knowledge communities (Vygotsky, 1978). From a social constructivist point of view, learning is considered an active process in which people construct their knowledge by relating it to their previous experiences in real situations through interaction with the social environment. Thus, learning occurs as learners improve their knowledge through collaboration and information sharing in authentic contexts. According to Vygotsky, language and culture play essential roles in human collaboration and communication. As a result, the socio-constructivist learning theory is essentially a collaborative learning theory. In education, collaborative learning is seen as a process of peer interaction that is mediated and structured by the teacher.

Vygostky's theory of Zone of Proximal Development (ZPD) expresses the social aspect of learning. ZPD is the "distance between the actual developmental level as determined by independent problem-solving and the level of potential development as determined through problem solving under adult guidance or in collaboration with more capable peers" (Vygotsky, 1978, p. 86). ZPD describes the tasks the learner can do, but only with help from a more knowledgeable person. This means that students can learn, but beyond a certain level, they cannot learn alone unless they are engaged in a level of activity that they cannot manage alone without the assistance of a more knowledgeable person. Vygostky's theory of ZDP is a useful construct to understand the tension between individual learning and collaboration with others. Students' learning development in an online collaborative environment should not be assessed by what they can learn independently with the tools alone, but rather by what they can learn in collaboration with fellow students (Buzzetto-More, 2010; Koohang, Riley, \& Smith, 2009).

\section{Community of Practice}

Collaborative learning becomes even more important when it takes place in the context of a community of practice (Wenger, 1998). A community of practice consists of people engaged in collective learning in a shared domain, where learning becomes a collaborative process of a group. In such communities, students collaborate as they acquire a common understanding of a shared knowledge domain (Lave \& Wenger, 1998). Students' participation in communities of practice is based on negotiation and renegotiation of the meaning of the shared domain. This means that understanding and experience are in constant interaction and mutually constitutive (pp. 51-52). Becoming a member of such a community includes learning how to collaborate in the community (p. 109). In this perspective, participation in online dialogue by means of collaborative tools can be seen as social practices and contextual negotiation of meaning. Collaborative writing is one example of a shared knowledge space where students come together as communities of learners to share knowledge as they generate content (Dubé, Bourhis, \& Jacob, 2006; Parker \& Chao, 2007). 


\section{Tools for Collaborative Writing}

Collaborative tools can serve as a knowledge platform for a community of practice where members of the community can share their knowledge with the group, post information, work together, and critically discuss issues (Cattafi \& Metzner, 2007). The use of collaborative tools is characterized by some of the elements fundamental to a community of practice, including an online presence, a variety of interactions, communication, participation, relevant content, and relationships to a broader subject field of interest. Collaborative tools can be used to facilitate computer-supported collaborative learning, i.e., the development of collaboration by means of technology to enhance learning. In addition, collaborative tools can enhance peer interaction and group work, facilitate sharing and distributing knowledge and information among a community of learners (Lipponen, 2002). Finally, an essential element of collaborative learning is that learners should be encouraged to reflect on their knowledge. Collaborative tools allow this reflection to be done collaboratively, moving closer to a fully social constructivist mode of learning.

\section{Collaborative Writing with Google Docs and EtherPad}

\section{Google Docs and EtherPad}

One set of Web 2.0 applications are collaborative writing tools, where several people collaborate on producing a document or a set of documents over the Web. Common applications are blogs and wikis. A blog is sequential, sharing content by posts and comments displayed in reverse chronological order, but a wiki allows for multiple users to edit each other's content (Bell, 2009). To modify a wiki page, however, the user must enter an edit-mode and then save a new version of the page (Bell, 2009), so a wiki also has a chronological structure. Thus editing is performed on a document previously written by another author. This may pose a problem as users may feel reluctant to edit other people's work and to have their own work edited by others (Blau \& Caspi, 2009).

Alternative collaborative writing applications enable synchronous editing and allow users to collaborate in real time. Examples are GD and EP. GD provides a suite of applications consisting of word processor - having most of the features found in standard word processors - spreadsheet, presentation tool, database, and survey tool. EP is less full featured, but is noted for being particu-

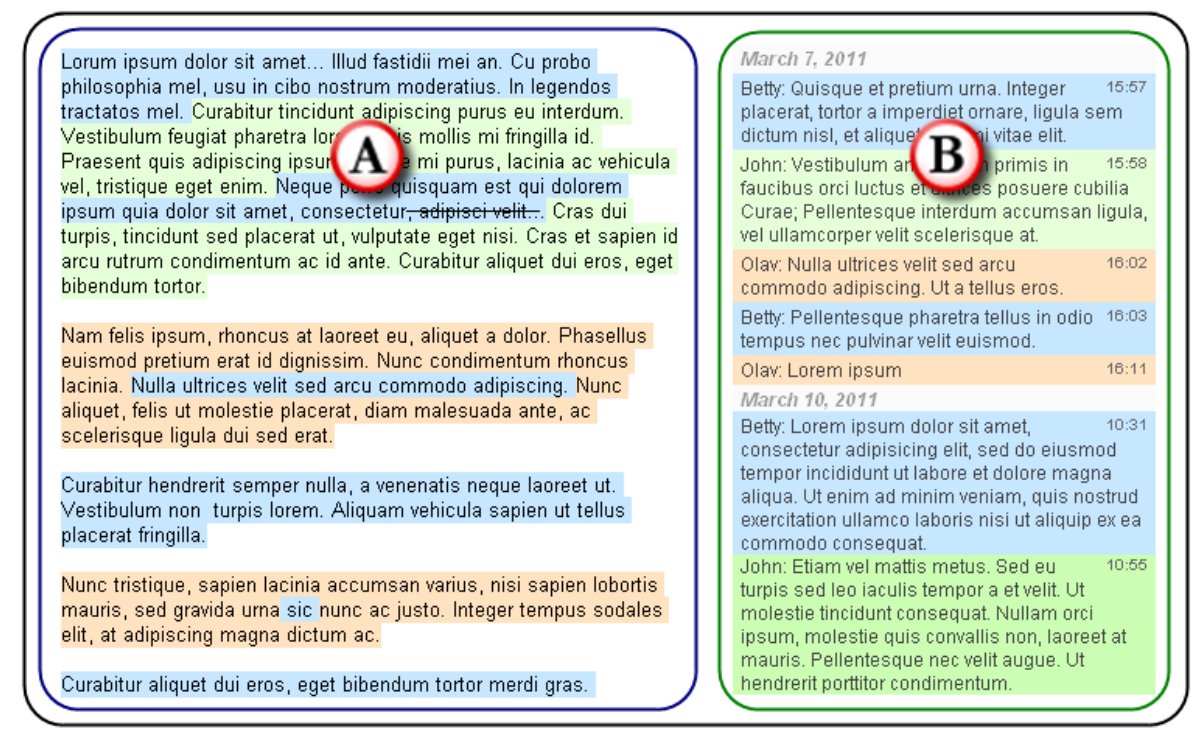

Figure 1: Schematic illustration of an editor with conversation space. Document editing takes place in pane $A$, non-threaded chat in pane $B$. Color coded highlights indicate author. 
larly easy to use (Hoya, 2010). Both applications are free. They differ however in that GD requires users to have an account, while EP is open to anybody. EP automatically provides each author with a unique highlight color and updates the document being edited continuously, i.e., every half second (EtherPad, 2008). Both GD and EP provide automatic saving and also allow the author to save at any time. Each saving produces a new document revision. Such revision tracking is a strong feature also provided by wikis. All three systems also offer a means for written metacommunication, in the form of separate discussion pages in wikis and chat fields (see Figure 1) in GD and EP.

\section{The Writing Process}

For the task-focused approach to collaborative writing, text editors conveying a conversation space were recommended and used (Figure 1). These types of co-authoring applications allow work modes and processes including synchronous and asynchronous co-located activity, as well as synchronous and asynchronous distributed activity. Authors are able to communicate by writing using artifacts, i.e., the editor (see A in Figure 1) and a conversation space (see B in Figure 1), as well as aurally. Understanding may come from direct communication and interaction through shared artifacts (Figure 2). With reference to the conceptual model of cooperative work (a, b, c, d, h) by Miles, McCarthy, Dix, Harrison, and Monk (1993), we extend this model to include collaborative writing and communication by means of chat integrated in the tools $(e, f, g)$ :

(a) Direct communication between participants.

(b) Participant's interaction with the document in editor.

(c) Indirect communication between participants through the document in editor.

(d) Participants' mutual establishment of various means to refer to the artifact in editor.

(e) Participant's interaction with other participant(s) in chat box.

(f) Online communication in chat box or through chat log.

(g) Participants' mutual establishment of various means to refer to the artifact in chat box.

(h) Common understanding from interaction through shared artifacts.

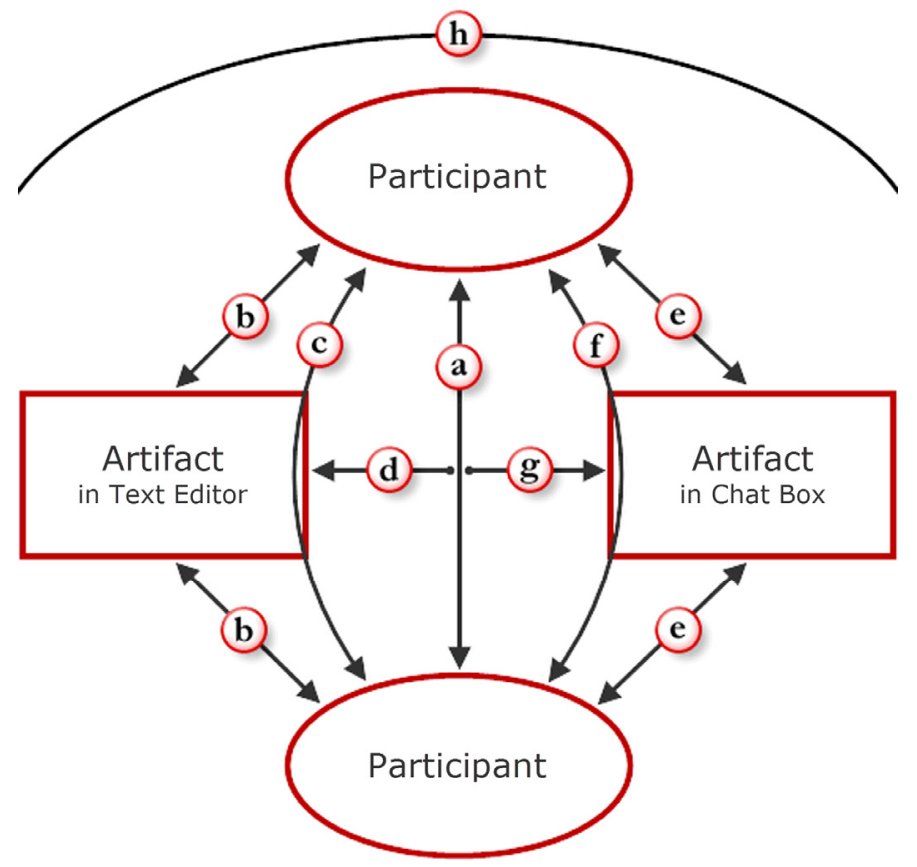

Figure 2: Extended conceptual model of collaborative writing, based on Miles et al. (1993). 
Collaborative writing using GD and EP is based on this model and utilized depending on the users' needs and learning styles in a real educational situation.

\section{Literature Review}

Looking at the research literature, it appears that published material related to Web 2.0 technologies in higher education is characterized by a number of issues: positive elements of use, advantages of using Web 2.0 technologies, critical issues regarding the pedagogical value of Web 2.0, and the role of the teacher in using these technologies.

First, the research literature reports on positive elements of use of Web 2.0 technologies as teaching tools. For example, Rienzo and Han (2009) found significant benefits of using GD in a management course with more than 400 students, and they anticipate additional benefits in the future, e.g., raising collaboration to a new level. Likewise, Tsoi (2010) reported that the outcomes of the process of integration of Web 2.0-mediated collaborative activities in terms of the richness of the contents of the blogs and wikis have been encouraging and positive. Furthermore, Rice (2009) claims collaborative writing in Web 2.0 environments not only to be a practical tool, but also a fluid, dialogical situation existing among writers, objects, and the informational contexts. Chu et al. (2009) reported on 14 undergraduate students in the Information Management Program, who found MediaWiki and GD to be an effective (and enjoyable) online collaboration and management tool. Blau and Caspi (2009) analyzed different types of students' collaboration on peers' written assignments using GD. They found differences in psychological ownership and perceived quality of the document, but not in their perceived learning, and believe that a collaboratively written document might have higher quality than a document written alone.

Second, the research literature also highlights the advantages of using Web 2.0 technologies. For example, Kittle and Hicks (2009) discuss, from new perspectives on literacies, issues about how learners work together and what online tools like word processors and wikis can enable, synchronously and asynchronously. They present sample procedures for how we can teach collaborative writing using technology and how to pay attention to what is happening in the document and mentally. Similarly, Lamb and Johnson (2010) considered, from the perspective of teacherlibrarians, GD as collective writing tool in inquiry-based education. They discussed ways writing tools can be used in facilitating teaching and learning in order to think, create, and share at the same time as addressing subject areas in the classroom. Also, Krebs, Schmidt, Henninger, Ludwig, and Müller (2010) think that weblogs and wikis are a promising way to improve students' learning and to impart their 21st century skills, but these assumptions are the best hypotheses. Empirical research is still necessary to confirm the potentialities of Web 2.0 for collaborative learning.

Third, apart from the advantages of using Web 2.0 technologies and the positive results achieved so far reported in the literature, there are still a number of critical issues regarding the educational value of Web 2.0 technologies in comparison to traditional ways of learning. The research literature reports on a number of studies on the use of Web 2.0 for collaboration in educational settings. Elgort, Smith, and Toland (2008) pointed out that many students still favor individual learning instead of working collaboratively, although wiki technologies require collaboration among students. According to Luckin et al. (2009), few learners reported engaging in genuine collaborative learning using Web 2.0 technologies. On the contrary, most learners reported that they did not work collaboratively. Furthermore, despite the potential capabilities of Web 2.0, Dron (2007) pointed out that the structure generated through social software intended to support collaboration and group interaction may not be pedagogically useful, and there are many ways that social software can fail to address the learners' needs. Criticisms are also expressed by Grion and Varisco (2007). They explored the shared construction of professional identity and the nature of interaction in students sharing their case-work, a synthesis of real life scholastic experiences 
and pedagogical theoretical reasoning, by means of a collaborative writing tool. They identified the need to provide a space for supporting these novice students to reflect more. Lastly, Brush and Saye (2009) succeeded using collaborative tools (like GD) for school visit inventory and empowering inquiry-based teaching practices in social studies classrooms, having pre-service teacher students collectively gather, analyze, and interpret information. However, they indicated that "even if mentor-teachers do have expertise in technology integration and time to mentor preservice teachers, they may not have the opportunity to model diverse teaching strategies in the limited amount of time a preservice teacher is present in their classroom, or they may lack of technology resources at a given placement school" (p. 59).

Finally, another important subject for discussion in the literature is the teacher's role in using Web 2.0 technologies. Parker and Chao (2007) think that the role of the teacher is as important as in the traditional classroom. Teachers still need to teach Web 2.0 as a skill, by incorporating social software into classroom, and to prepare students to make innovative uses of collaborative software tools. Likewise, Kim, Hong, Bonk, and Lim (2009) stress that effective teacher intervention is a crucial component leading to better group performance, collaboration, and reflection. In contrast, Prensky (2010) claims Web 2.0 technology to be a tool that students use for learning essential skills and "getting things done" (p. 103) and that students should be encouraged to use Web 2.0 tools as much as possible - not necessarily teach them to use technology.

\section{Methodology}

\section{Case Study}

This case study is about students' perceptions of collaborative writing tools in a higher education setting, where focus is on educational objectives, not on teaching the tools. The case study is based on a set of research questions and initial hypotheses and uses both quantitative and qualitative data collection methods. This paper is only on the quantitative part of the work. The case study also draws on a theoretical framework associated with learning theories and the link to collaborative tools. The case study includes a community of students from two campuses at the same university.

A case study research was chosen for three reasons. First, it provides a suitable context for the research questions and the research hypotheses. Second, it helps to find out whether the results support the theoretical framework and existing research work. Third, it uses methods to collect both quantitative and qualitative data and their triangulation to achieve an adequate understanding of the students' perceptions of GD and EP.

The case study is a part of a larger research and development project (R\&D) aiming to enhance students' digital competence and collaborative skills as an activity in a multi-step introduction of Web 2.0 technology. Nevertheless, the case may stand alone shedding light on challenges with introducing collaborative Web 2.0 writing tools.

\section{Background for the Case Study}

In comparable countries in Europe, there are differences in national ICT related policies and ICT competence targets in initial teacher education (European Schoolnet, 2010). In Norway, there are targets set for ICT competence for teachers related to use in subjects, but there is no standard or target aimed at teachers' overall ICT competence (Søby, 2009). The policy for ICT integration in teacher training has been introduced at the national level in the new program for initial teacher education (Norwegian Ministry of Education and Research, 2009), to be incorporated into the institutional policies. In preparing its curriculum and syllabus, each teacher training institution has to state how digital competences should be built. The challenge then is, within the teacher 
training institution, to encourage both the teacher educators responsible for teaching a specific school subject and the educational science subject teachers to operationalize the ICT policy in their teaching (Tømte, Hovdhaugen \& Solum, 2009).

\section{Research and Development Project (R \& D)}

At the University of Agder, with the educational science subject teachers' looking for space and opportunities for students to acquire and practice ICT in the new, expanded subject Pedagogy and Pupil-related Skills (PPS), the Faculty of Science and Technology established a project to run for three years. The main goal of this project, "Learning Arena 2020 - Web 2.0", is to utilize Web 2.0 to create new arenas for collaborative learning. The project investigates learning based on adopting social networking and collaborative technologies. Particular focus is given to the design and organization of learning activities and to the potential methods and ways of learning they might create. The main target group is students in a variety of teacher education programs with the clear goal of spreading experiences to the teachers and pupils in schools. The first step of the project included collaboration with the educational science subject teachers, both at the main campus $(\mathrm{C} 1)$ and the satellite campus $(\mathrm{C} 2)$. While the main campus offers a wide variety of educational studies, the satellite campus has a technology and engineering profile and focuses on mathematics and science as major areas of study in teacher education.

\section{Key Elements of the Case Study}

The researchers and collaborating educational science subject teachers designed a mandatory group task for the education students in the second month of their education, as a jump-start to utilizing Web 2.0 tools in collaborative learning. The development of the task was based on the following premises and presumptions:

- Focus should be on the content of the new subject, not on technical skills and tools.

- Web 2.0 technologies should supposedly be easy to use and take little time to learn.

- An introduction of tools might be needed, but with emphasis on good use and motivation, not details.

Beyond covering subject content, the task was to be designed with the intention of providing opportunities for students to acquire and practice ICT skills, in particular applications and technologies allowing for engaging and connecting with others, as well as experiencing implications for learning strategies.

The assignment was presented by the educational science subject teachers, and the use of a Webbased collaborative real-time editor was made mandatory. The assignment consisted of writing narratives of practice, based on theory and experience from ongoing first practical training in elementary school, and working in groups of four to seven students. The tasks were slightly different at the two campuses because of different priorities given by the local team of campus teachers: the focus at C1 was on a teacher's role and at C2 on the students' first teaching load. Each base group, consisting of five to seven persons at $\mathrm{C} 1$ and four persons at $\mathrm{C} 2$, worked on the same task and was required to collaboratively write a two to three page reflective essay paper using either GD or EP.

Apart from formal writing requirement and a five-minute demonstration of each of the two writing tools, no detailed training was given, expecting the students with equal ease to find their way to explore and utilize the writing tool while working on their subject assignment. 


\section{Participants}

The work used a convenience sample for two reasons. First, the participants were directly accessible to the researcher. Second, students were expected to take part in an online survey, resulting in a high response rate.

The sample included all beginner education students $(N=201)$ in the university Teacher Education Unit (see Table 1).

- The participants consisted of $71.1 \%$ females and $28.9 \%$ males with a mean age of 22.4 years and a median age of 20.5 .

- Ages ranged from 18.8 to 44.2 years.

- Students were enrolled in one of two courses, $48.3 \%$ and $51.7 \%$ respectively: Primary Education program (PE) for grades 1-7 in 10-year compulsory schooling and Lower Secondary Education program (LSE) for grades 5-10.

- Three LSE-classes (R, S and T) were held on main campus (C1), as did two PE-classes $(\mathrm{U}$ and $\mathrm{V})$. One class $(\mathrm{W})$ attended the PE-program on the satellite campus (C2).

Table 1: Students' age and gender distribution related to classes, study programs and locations with different educational settings.

\begin{tabular}{|c|c|c|c|c|c|c|c|c|c|c|c|}
\hline \multirow[b]{2}{*}{$\mathrm{L}$} & \multirow[b]{2}{*}{ SP } & \multirow[b]{2}{*}{ C } & \multicolumn{3}{|c|}{ Aged 19-27 } & \multicolumn{3}{|c|}{ Aged 28-44 } & \multicolumn{3}{|c|}{ All ages } \\
\hline & & & Female & Male & Subtotal & Female & Male & Subtotal & Female & Male & Subtotal \\
\hline$\overline{\mathrm{C} 1}$ & LSE & $\mathrm{R}$ & $\begin{array}{c}\mathbf{1 9} \\
(51.4)\end{array}$ & $\begin{array}{c}\mathbf{1 5} \\
(40.5)\end{array}$ & $\begin{array}{c}\mathbf{3 4} \\
(91.9)\end{array}$ & $\begin{array}{c}\mathbf{0} \\
(0.0)\end{array}$ & $\begin{array}{c}\mathbf{3} \\
(8.1)\end{array}$ & $\begin{array}{c}\mathbf{3} \\
(8.1)\end{array}$ & $\begin{array}{c}\mathbf{1 9} \\
(51.4)\end{array}$ & $\begin{array}{c}\mathbf{1 8} \\
(48.6)\end{array}$ & $\begin{array}{c}\mathbf{3 7} \\
(100.0)\end{array}$ \\
\hline $\mathrm{Cl}$ & LSE & $\mathrm{S}$ & $\begin{array}{c}\mathbf{2 2} \\
(71.0)\end{array}$ & $\begin{array}{c}\mathbf{6} \\
(19.4)\end{array}$ & $\begin{array}{c}\mathbf{2 8} \\
(90.3)\end{array}$ & $\begin{array}{c}\mathbf{2} \\
(6.5)\end{array}$ & $\begin{array}{c}\mathbf{1} \\
(3.2)\end{array}$ & $\begin{array}{c}\mathbf{3} \\
(9.7)\end{array}$ & $\begin{array}{c}\mathbf{2 4} \\
(77.4)\end{array}$ & $\begin{array}{c}7 \\
(22.6)\end{array}$ & $\begin{array}{c}\mathbf{3 1} \\
(100.0)\end{array}$ \\
\hline $\mathrm{Cl}$ & LSE & $\mathrm{T}$ & $\begin{array}{c}\mathbf{1 9} \\
(52.8)\end{array}$ & $\begin{array}{c}\mathbf{1 3} \\
(36.1)\end{array}$ & $\begin{array}{c}\mathbf{3 2} \\
(88.9)\end{array}$ & $\begin{array}{c}\mathbf{2} \\
(5.6)\end{array}$ & $\begin{array}{c}\mathbf{2} \\
(5.6)\end{array}$ & $\begin{array}{c}\mathbf{4} \\
(11.1)\end{array}$ & $\begin{array}{c}\mathbf{2 1} \\
(58.3)\end{array}$ & $\begin{array}{c}\mathbf{1 5} \\
(41.7)\end{array}$ & $\begin{array}{c}\mathbf{3 6} \\
(100.0)\end{array}$ \\
\hline $\mathrm{Cl}$ & PE & $\mathrm{U}$ & $\begin{array}{c}\mathbf{2 7} \\
(73.0)\end{array}$ & $\begin{array}{c}\mathbf{6} \\
(16.2)\end{array}$ & $\begin{array}{c}\mathbf{3 3} \\
(89.2)\end{array}$ & $\begin{array}{c}\mathbf{4} \\
(10.8)\end{array}$ & $\begin{array}{c}\mathbf{0} \\
(0.0)\end{array}$ & $\begin{array}{c}\mathbf{4} \\
(10.8)\end{array}$ & $\begin{array}{c}\mathbf{3 1}) \\
(83.8)\end{array}$ & $\begin{array}{c}\mathbf{6} \\
(16.2)\end{array}$ & $\begin{array}{c}37 \\
(100.0)\end{array}$ \\
\hline $\mathrm{Cl}$ & PE & V & $\begin{array}{c}\mathbf{2 9} \\
(80.6)\end{array}$ & $\begin{array}{c}\mathbf{3} \\
(8.3)\end{array}$ & $\begin{array}{c}32 \\
(88.9)\end{array}$ & $\begin{array}{c}\mathbf{4} \\
(11.1)\end{array}$ & $\begin{array}{c}\mathbf{0} \\
(0.0)\end{array}$ & $\begin{array}{c}\mathbf{4} \\
(11.1)\end{array}$ & $\begin{array}{c}\mathbf{3 3} \\
(91.7)\end{array}$ & $\begin{array}{c}\mathbf{3} \\
(8.3)\end{array}$ & $\begin{array}{c}36 \\
(100.0)\end{array}$ \\
\hline $\mathrm{C} 2$ & PE & W & $\begin{array}{c}13 \\
(54.2)\end{array}$ & $\begin{array}{c}7 \\
(29.2)\end{array}$ & $\begin{array}{c}\mathbf{2 0} \\
(83.3)\end{array}$ & $\begin{array}{c}\mathbf{2} \\
(8.3)\end{array}$ & $\begin{array}{c}\mathbf{2} \\
(8.3)\end{array}$ & $\begin{array}{c}\mathbf{4} \\
(16.7)\end{array}$ & $\begin{array}{c}15 \\
(62.5)\end{array}$ & $\begin{array}{c}9 \\
(37.5)\end{array}$ & $\begin{array}{c}\mathbf{2 4} \\
(100.0)\end{array}$ \\
\hline & otal & & $\begin{array}{c}\mathbf{1 2 9} \\
(64.2)\end{array}$ & $\begin{array}{c}\mathbf{5 0} \\
(24.9)\end{array}$ & $\begin{array}{c}\mathbf{1 7 9} \\
(89.1)\end{array}$ & $\begin{array}{c}\mathbf{1 4} \\
(7.0)\end{array}$ & $\begin{array}{c}\mathbf{8} \\
(4.0)\end{array}$ & $\begin{array}{c}\mathbf{2 2} \\
(10.9)\end{array}$ & $\begin{array}{c}\mathbf{1 4 3} \\
(71.1)\end{array}$ & $\begin{array}{c}\mathbf{5 8} \\
(28.9)\end{array}$ & $\begin{array}{c}\mathbf{2 0 1} \\
(100.0)\end{array}$ \\
\hline
\end{tabular}

Note. Numbers of students are shown in boldface, percentage is italicized and parenthesized. $\mathrm{L}=$ Location $(\mathrm{C} 1=$ main campus; $\mathrm{C} 2=$ satellite campus); $\mathrm{SP}=$ Study program ( $\mathrm{LSE}=$ Lower Secondary Education; $\mathrm{PE}=$ Primary Education); $\mathrm{C}=$ class-name

Three classes (R, S, and T) with a total of 104 students attended the lower secondary education program (LSE) for grades 1-7 being held on the main campus (C1), as did two classes (U and V) with a total of 73 students in the program for primary education (PE) for grades 5-10. One class (W) comprising of 24 students also attended the latter program on the satellite campus (C2).

Each class was organized in 35 basic work groups. The 29 groups on the main campus consisted of 5-7 students each, with a mean age between 19.8 and 27.4 years. The six groups on the satellite campus consisted of four students each, with a mean age varying from 21.0 to 31.8 years. 
A show of hands, after a demonstration of GD and EP, revealed that none of the students present had used EP before. Less than 2\% had used GD: one student on satellite and three students on main campus.

Relying on the concept of Digital Natives as defined by Prensky (2001, p.1) and overall characterized as possessing a core set of technology based skills (Kennedy, Judd, Churchward, Gray, \& Krause, 2008, p. 117), this research work designates all students born after 1983, who were 27 or younger at the time of the study, as a part of the Net generation of Digital Natives in Europe (Jones, Ramanau, Cross, and Healing, 2010, p. 724). Accordingly, 89.1\% of the first-year students are considered as Digital Natives.

\section{Data Collection Methods}

While the project has gathered data from multiple sources (i.e., group works, reflection notes, peer comments, survey), this study is confined to a survey. Data triangulation on remaining material will be effected in subsequent studies.

After completing their collaborative writing, the students were asked to take an electronic survey using a Web form presented on the main page of the Web site used for their reflective essay paper. This Web site was built using the content management system Drupal (http://drupal.org/), and the survey was constructed with Drupal Webform (http://drupal.org/project/webform/).

The survey used a five-point Likert scale as follows: Strongly agree (SA), Agree (A); Neither agree nor disagree (NAD); Disagree (D); and Strongly disagree (SD). In addition, a category "Don't Know" was added since some students might be expected to be unsure about how to answer. The survey questionnaire reflects the research questions. Since it is an online survey, the issue of anonymity has been taken into account to indicate that students' answers would be treated confidentially. The Webform module was used for collecting and processing responses. Also, using a Webform parameter, multiple answers were excluded.

The survey was originally open for 4 days at campus $\mathrm{C} 1$ and 2 days on campus $\mathrm{C} 2$. But the number of respondents was low, so it was reopened for 2 days on campus $\mathrm{C} 1$ and 3 days on campus $\mathrm{C} 2$. Non-responding students on $\mathrm{C} 2$ were also given the opportunity to respond during a lesson, and individual students were granted access on request. The survey had the following characteristics:

- Respondents were not anonymous, thus gender, age, and group size was known a priori. Use of non-anonymous respondents also gives opportunity for linking responses and student essays in later research.

- Issues included digital competence, satisfaction with the collaborative process, satisfaction with the collaborative writing tool, and opinions on cooperative writing. The students were also asked to state their own digital competence, how well they liked to work with digital tools, and how important they expected digital competence to be in their future work as a teacher.

- Digital competence was estimated based on students' replies as to how often they performed certain common computer tasks, ranging from Never to Daily. Each task was assigned a skill level ranging from 1 (Low) to 5 (High), corresponding to key concepts of ICT literacy (Erstad, 2009). (See Appendix A, Table A1 for more details). The frequency of performing a task was assigned a value on a scale ranging from 0 (Never, Don't know) to 7 (Daily). The scale was logarithmic, reflecting the conceptual smaller difference between Daily and Weekly as opposed to Never and Less than monthly. (See Appendix A, Table A2 for more details). By multiplying each skill level (Table A1) with the corresponding frequency value (Table A2), a set of products in the range $[0,35]$ were ob- 
tained. To avoid many basic skills counting as equal to a few advanced skills, the numbers were not averaged. Instead the largest product was chosen as an indicator of digital competence, and classified on a scale ranging from Very low to Very high. (See Appendix A, Table A3 for more details).

- Due to decisions made by the campus teachers, the survey was mandatory in class R, S, $\mathrm{T}, \mathrm{U}$ and $\mathrm{V}$ at campus $\mathrm{C} 1$, and optional in class $\mathrm{W}$ at campus $\mathrm{C} 2$.

\section{Preliminary Results}

The work focuses on the quantitative results of the survey questionnaires. It does not analyze students' comments or reflective essay papers. Without a qualitative analysis of these, the results must be considered with caution. As we search for dissimilarities in response distribution between two groups, the results are presented as frequency distribution tables with the groups compared in juxtaposition. The focus was not on distribution details within each group, i.e., mean and standard deviation.

A total of 166 students $(83.6 \%$ of $N=201)$ participated in the survey: $154(87 \%$ of $n=177)$ on main campus, and $12(50 \%$ of $n=24)$ on satellite campus. In the following, the preliminary results describe the students' perceptions of the:

- collaborative tool, including ease-of-use and effectiveness (See Table 2, statements 1-3)

- collaborative process, supported by the tool (See Table 2, statements 4-8).

\section{Students' Perceptions of Collaborative Writing, Global View}

Table 2 presents a count of responses to the statements concerning the collaborative tool, the collaborative process, and how well the collaborative tool worked.

Concerning the ease-of-use and effectiveness of the tool, $38.6 \%$ agreed or strongly agreed that the tool was easy to use. Likewise, only $26.5 \%$ of the students thought that the tool was effective to use in group work. Furthermore, $32.5 \%$ found that the tool is easier to use than traditional text processing. While only $31.3 \%$ of the students liked to comment and edit others work, $47.6 \%$ strongly agreed or agreed that other students comment and edit their own work. In addition, only $15.7 \%$ of the students found that the tool influenced the quality of collaborative work within the group. Furthermore, only $13.9 \%$ were motivated to use the tools for collaboration with their fellow students. Regarding the learning effect of collaborative work, 34.9\% strongly agreed or agreed that they learned by collaborating. Finally, $16.9 \%$ of the students indicated that the tool did work as expected

The results must be interpreted cautiously depending on the analysis of further information, since more than $30 \%$ of the students neither agreed nor disagreed to any of the statements, except for statement 9 (See Table 2). An explanation of this uncertainty may be lack of experience with the tools, but other causes may be the students' digital competence and lack of time to work with the tool. Thus it is difficult to assess the real value of collaboration by means of GD and EP. However, it is possible to draw some provisory conclusions:

- An important number of students (47.6\%) were not motivated to use the tools for collaboration.

- The tools did not work as expected for the overwhelming majority of the students $(70.5 \%)$.

- The tools did not significantly affect the quality of collaboration between the students. 
Table 2: Students' perceptions of collaborative writing, global view

\begin{tabular}{|c|c|c|c|c|c|c|c|c|c|}
\hline \multirow{2}{*}{\multicolumn{2}{|c|}{ Statement }} & \multicolumn{8}{|c|}{ Response $^{a}$} \\
\hline & & \multirow{2}{*}{$\begin{array}{c}\begin{array}{c}\text { Strongly } \\
\text { agree } \\
\text { (SA) }\end{array} \\
\mathbf{9} \\
(5.4)\end{array}$} & \multirow{2}{*}{$\begin{array}{c}\text { Agree } \\
\text { (A) } \\
\mathbf{5 5} \\
(33.1)\end{array}$} & \multirow{2}{*}{$\begin{array}{c}\begin{array}{c}\text { Neither } \\
\text { agree } \\
\text { nor } \\
\text { disagree }\end{array} \\
\begin{array}{c}\mathbf{5 4} \\
(32.5)\end{array}\end{array}$} & \multirow{2}{*}{$\begin{array}{c}\text { Disagree } \\
\text { (D) } \\
\mathbf{3 8} \\
(22.9)\end{array}$} & \multirow{2}{*}{$\begin{array}{c}\text { Strongly } \\
\text { disagree } \\
\text { (SA) }\end{array}$} & \multirow{2}{*}{$\begin{array}{c}\begin{array}{c}\text { Don't } \\
\text { know }\end{array} \\
\mathbf{0} \\
(0.0)\end{array}$} & \multirow{2}{*}{$\begin{array}{c}\text { Sub- } \\
\text { total } \\
\text { SA+A } \\
64 \\
(38.6)\end{array}$} & \multirow{2}{*}{ 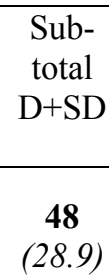 } \\
\hline 1. & $\begin{array}{l}\text { It was easy to use the tool } \\
\text { in group work }\end{array}$ & & & & & & & & \\
\hline 2. & $\begin{array}{l}\text { It was effective to use the } \\
\text { tool in group work }\end{array}$ & $\begin{array}{c}\mathbf{8} \\
(4.8)\end{array}$ & $\begin{array}{c}\mathbf{3 6} \\
(21.7)\end{array}$ & $\begin{array}{c}\mathbf{6 0} \\
(36.1)\end{array}$ & $\begin{array}{c}44 \\
(26.5)\end{array}$ & $\begin{array}{c}17 \\
(10.2)\end{array}$ & $\begin{array}{c}1 \\
(0.6)\end{array}$ & $\begin{array}{c}\mathbf{4 4} \\
(26.5)\end{array}$ & $\begin{array}{c}\mathbf{6 1} \\
(36.7)\end{array}$ \\
\hline 3. & $\begin{array}{l}\text { The tool was easier to use } \\
\text { than traditional tools such } \\
\text { as MS Word }\end{array}$ & $\begin{array}{c}7 \\
(4.2)\end{array}$ & $\begin{array}{c}\mathbf{4 7} \\
(28.3)\end{array}$ & $\begin{array}{c}\mathbf{5 2} \\
(31.3)\end{array}$ & $\begin{array}{c}\mathbf{4 2} \\
(25.3)\end{array}$ & $\begin{array}{c}17 \\
(10.2)\end{array}$ & $\begin{array}{c}1 \\
(0.6)\end{array}$ & $\begin{array}{c}\mathbf{5 4} \\
(32.5)\end{array}$ & $\begin{array}{c}\mathbf{5 9} \\
(35.5)\end{array}$ \\
\hline 4. & $\begin{array}{l}\text { I liked to comment and } \\
\text { edit others contributions to } \\
\text { group work }\end{array}$ & $\begin{array}{c}9 \\
(5.4)\end{array}$ & $\begin{array}{c}43 \\
(39.8)\end{array}$ & $\begin{array}{c}\mathbf{5 9} \\
(35.5)\end{array}$ & $\begin{array}{c}38 \\
(9.0)\end{array}$ & $\begin{array}{c}9 \\
(3.0)\end{array}$ & $\begin{array}{c}\mathbf{8} \\
(4.8)\end{array}$ & $\begin{array}{c}\mathbf{5 2} \\
(31.3)\end{array}$ & $\begin{array}{c}\mathbf{4 7} \\
(28.3)\end{array}$ \\
\hline 5. & $\begin{array}{l}\text { I liked that other students } \\
\text { comment and edit my own } \\
\text { work in the group }\end{array}$ & $\begin{array}{c}\mathbf{1 3} \\
(7.8)\end{array}$ & $\begin{array}{c}\mathbf{6 6} \\
(39.8)\end{array}$ & $\begin{array}{c}\mathbf{5 9} \\
(35.5)\end{array}$ & $\begin{array}{l}\mathbf{1 5} \\
(9.0)\end{array}$ & $\begin{array}{c}\mathbf{5} \\
(3.0)\end{array}$ & $\begin{array}{c}\mathbf{8} \\
(4.8)\end{array}$ & $\begin{array}{c}79 \\
(47.6)\end{array}$ & $\begin{array}{l}\mathbf{2 0} \\
(12.0)\end{array}$ \\
\hline 6. & $\begin{array}{l}\text { The quality of collabora- } \\
\text { tion in the group increased } \\
\text { with the use of the tool }\end{array}$ & $\begin{array}{c}\mathbf{6} \\
(3.6)\end{array}$ & $\begin{array}{c}\mathbf{2 0} \\
(12.0)\end{array}$ & $\begin{array}{c}\mathbf{5 4} \\
(32.5)\end{array}$ & $\begin{array}{c}46 \\
(27.7)\end{array}$ & $\begin{array}{c}33 \\
(19.9)\end{array}$ & $\begin{array}{c}7 \\
(4.2)\end{array}$ & $\begin{array}{c}\mathbf{2 6} \\
(15.7)\end{array}$ & $\begin{array}{c}79 \\
(47.6)\end{array}$ \\
\hline 7. & $\begin{array}{l}\text { The tool motivated me to } \\
\text { collaborate with the stu- } \\
\text { dents in the group }\end{array}$ & $\begin{array}{c}\mathbf{3} \\
(1.8)\end{array}$ & $\begin{array}{c}\mathbf{2 0} \\
(12.0)\end{array}$ & $\begin{array}{c}\mathbf{6 2} \\
(37.3)\end{array}$ & $\begin{array}{c}\mathbf{5 1} \\
(30.7)\end{array}$ & $\begin{array}{c}\mathbf{2 8} \\
(16.9)\end{array}$ & $\begin{array}{c}\mathbf{2} \\
(1.2)\end{array}$ & $\begin{array}{c}\mathbf{2 3} \\
(13.9)\end{array}$ & $\begin{array}{c}79 \\
(47.6)\end{array}$ \\
\hline 8. & $\begin{array}{l}\text { It was instructive to edit } \\
\text { and comment others con- } \\
\text { tributions to group work }\end{array}$ & $\begin{array}{c}\mathbf{5} \\
(3.0)\end{array}$ & $\begin{array}{c}\mathbf{5 3} \\
(31.9)\end{array}$ & $\begin{array}{c}\mathbf{6 8} \\
(41.0)\end{array}$ & $\begin{array}{c}\mathbf{2 1} \\
(12.7)\end{array}$ & $\begin{array}{c}\mathbf{1 3} \\
(7.8)\end{array}$ & $\begin{array}{c}6 \\
(3.6)\end{array}$ & $\begin{array}{c}\mathbf{5 8} \\
(34.9)\end{array}$ & $\begin{array}{c}\mathbf{3 4} \\
(20.5)\end{array}$ \\
\hline 9. & $\begin{array}{l}\text { The tool did work as ex- } \\
\text { pected }\end{array}$ & $\begin{array}{c}\mathbf{8} \\
(4.8)\end{array}$ & $\begin{array}{c}\mathbf{2 0} \\
(12.0)\end{array}$ & $\begin{array}{c}18 \\
(10.8)\end{array}$ & $\begin{array}{c}\mathbf{5 1} \\
(30.7)\end{array}$ & $\begin{array}{c}\mathbf{6 6} \\
(39.8)\end{array}$ & $\begin{array}{c}\mathbf{3} \\
(1.8)\end{array}$ & $\begin{array}{c}\mathbf{2 8} \\
(16.9)\end{array}$ & $\begin{array}{c}\mathbf{1 1 7} \\
(70.5)\end{array}$ \\
\hline
\end{tabular}

Note. Frequency of responses is in boldface, percentage is italicized and parenthesized. ${ }^{a} n=166$

\section{Students' Perceptions of Collaborative Writing: Detailed Views}

Tables 3.1 to 3.8 show how the percentage of positive (Strongly agree and Agree), neutral (Neither agree nor disagree and Don't know), and negative (Disagree and Strongly disagree) responses to statements 1-3 (collaborative tool) and 4-8 (collaborative process) vary with gender, age, perceptions of digital competence, educational setting, and whether they used GD or EP.

\section{Gender}

Table 3.1 indicates that females were more negative than males regarding the collaborative tool $(36.4 \% / 26.4 \%)$ and process $(33.5 \% / 25.2 \%)$. (See Appendix B, Table B1 for more details). 
Table 3.1: Students' perceptions of collaborative writing according to gender

\begin{tabular}{|c|c|c|c|c|c|c|c|}
\hline \multirow[b]{2}{*}{$\begin{array}{l}\text { Statement } \\
\text { category }\end{array}$} & \multirow[b]{2}{*}{$\begin{array}{c}\text { Statement } \\
n^{\circ}\end{array}$} & \multicolumn{3}{|c|}{$\begin{array}{c}\text { Male } \\
(n=46)\end{array}$} & \multicolumn{3}{|c|}{$\begin{array}{c}\text { Female } \\
(n=120)\end{array}$} \\
\hline & & Positive & Neutral & Negative & Positive & Neutral & Negative \\
\hline Collaborative tool & $1-3$ & 33.5 & 37.7 & 26.8 & 31.4 & 32.2 & 36.4 \\
\hline Collaborative process & $4-8$ & 32.2 & 42.6 & 25.2 & 27.3 & 39.2 & 33.5 \\
\hline
\end{tabular}

Note. Average on frequency (\%): Positive responses include responses Strongly agree or Agree, neutral responses Neither agree nor disagree and Don't know, negative responses Disagree and Strongly disagree.

\section{Age}

Table 3.2 shows that Digital Immigrants (age 28-44) were more positive regarding the collaborative tool (39.2\% / 31.8\%) than Digital Natives, that is to say, first-year students born after 1983 or later at the time of the study (Jones et al., 2010, p. 724). They were however less positive regarding the collaborative process $(22.4 \%$ / 29.4\%). But, the results should be considered with caution, as only 17 digital immigrants responded to the questionnaire. (See Appendix B, Table B2, for more details).

Table 3.2: Students' perceptions of collaborative writing according to age

\begin{tabular}{|c|c|c|c|c|c|c|c|}
\hline \multirow[b]{2}{*}{$\begin{array}{c}\text { Statement } \\
\text { category }\end{array}$} & \multirow[b]{2}{*}{$\begin{array}{l}\text { Statement } \\
n^{\circ}\end{array}$} & \multicolumn{3}{|c|}{$\begin{array}{l}\text { Age } 19-27 \\
(n=149)\end{array}$} & \multicolumn{3}{|c|}{$\begin{array}{c}\text { Age } 28-44 \\
(n=17)\end{array}$} \\
\hline & & Positive & Neutral & Negative & Positive & Neutral & Negative \\
\hline Collaborative tool & $1-3$ & 31.8 & 33.6 & 34.7 & 39.2 & 35.3 & 25.5 \\
\hline$\underline{\text { Collaborative process }}$ & $4-8$ & 29.4 & 39.3 & 31.3 & 22.4 & 47.1 & 30.6 \\
\hline
\end{tabular}

Note. Average on frequency (\%): Positive responses include responses Strongly agree or Agree, neutral responses Neither agree nor disagree and Don't know, negative responses Disagree and Strongly disagree.

\section{Digital competence}

The students' digital competence was estimated based on how often they performed certain tasks on a computer; they were asked to state their perception of own digital competence, how much they liked to work with digital tools, and how important they imagined digital tools would be in their future work as a teacher (see section "Key Elements of the Case").

Table 3.3 shows that students assessing their own digital competence as high or very high tended to be more negative regarding the collaborative tool than those with medium or lower perception $(35.1 \% / 30.9 \%)$, but more positive regarding the collaborative process $(30.0 \% / 25.9 \%)$. (See Appendix B, Table B3 for more details).

Table 3.4, on the other hand, shows that students with high or very high estimated digital competence were more positive regarding the collaborative tool $(41.7 \%$ / 29.2\%) and less negative regarding the collaborative process $(25.9 \% / 33.1 \%)$. An explanation of this contradiction may be that the students' perception of own digital competence was too high. $67 \%$ of the students perceived their own digital competence as higher than estimated, $38 \%$ as estimated, and $10 \%$ as lower than estimated. (See Appendix B, Table B4 for more details). 
Table 3.5 shows that students with high or very high interest in digital tools were more positive regarding the collaborative tool $(35.4 \%$ / $26.7 \%)$ and the collaborative process $(32.6 \% / 20.7 \%)$. (See Appendix B, Table B5 for more details).

Table 3.6 shows that students who thought that digital tools will be of high or very high importance in their future work as a teacher were more neutral regarding the collaborative tool $(35.1 \%$ / $30.7 \%$ ) and more positive regarding the collaborative process $(32.5 \% / 20.0 \%)$. (See Appendix B, Table B6 for more details).

Table 3.3: Students' perceptions of collaborative writing according to own perception of digital competence

\begin{tabular}{|c|c|c|c|c|c|c|c|}
\hline \multirow[b]{2}{*}{$\begin{array}{l}\text { Statement } \\
\text { category }\end{array}$} & \multirow[b]{2}{*}{$\begin{array}{c}\text { Statement } \\
n^{\circ}\end{array}$} & \multicolumn{3}{|c|}{$\begin{array}{c}\text { Medium, low, very low, } \\
\text { Don't know } \\
(n=54)\end{array}$} & \multicolumn{3}{|c|}{$\begin{array}{l}\text { High, very high } \\
\quad(n=112)\end{array}$} \\
\hline & & Positive & Neutral & Negative & Positive & Neutral & Negative \\
\hline ollahorative tool & $1-3$ & 33.3 & 35.8 & 30.9 & 32.1 & 32.7 & 35.1 \\
\hline Collaborative process & $4-8$ & 25.9 & 42.2 & 31.9 & 30.0 & 39.1 & 30.9 \\
\hline
\end{tabular}

Note. Average on frequency (\%): Positive responses include responses Strongly agree or Agree, neutral responses Neither agree nor disagree and Don't know, negative responses Disagree and Strongly disagree.

Table 3.4: Students' perceptions of collaborative writing according to estimated digital competence

\begin{tabular}{|c|c|c|c|c|c|c|c|}
\hline \multirow[b]{2}{*}{$\begin{array}{l}\text { Statement } \\
\text { category }\end{array}$} & \multirow[b]{2}{*}{$\begin{array}{c}\text { Statement } \\
n^{\circ}\end{array}$} & \multicolumn{3}{|c|}{$\begin{array}{c}\text { Medium, low, very low, } \\
\text { Don't know } \\
(n=122)\end{array}$} & \multicolumn{3}{|c|}{$\begin{array}{l}\text { High, very high } \\
\qquad(n=44)\end{array}$} \\
\hline & & Positive & Neutral & Negative & Positive & Neutral & Negative \\
\hline Collaborative tool & $1-3$ & 29.2 & 33.9 & 36.9 & 41.7 & 33.3 & 25.0 \\
\hline Collaborative process & $4-8$ & 27.2 & 39.7 & 33.1 & 32.7 & 41.4 & 25.9 \\
\hline
\end{tabular}

Note. Average on frequency (\%): Positive responses include responses Strongly agree or Agree, neutral responses Neither agree nor disagree and Don't know, negative responses Disagree and Strongly disagree.

\section{Table 3.5: Students' perceptions of collaborative writing according to interest in digital tools}

\begin{tabular}{|c|c|c|c|c|c|c|c|}
\hline \multirow[b]{2}{*}{$\begin{array}{l}\text { Statement } \\
\text { category }\end{array}$} & \multirow[b]{2}{*}{$\begin{array}{c}\text { Statement } \\
\mathrm{n}^{\mathrm{o}}\end{array}$} & \multicolumn{3}{|c|}{$\begin{array}{c}\text { Medium, low, very low, } \\
\text { Don't know } \\
(n=55)\end{array}$} & \multicolumn{3}{|c|}{$\begin{array}{c}\text { High, very high } \\
(n=111)\end{array}$} \\
\hline & & Positive & Neutral & Negative & Positive & Neutral & Negative \\
\hline horative tol & $1-3$ & 26.7 & 32.7 & 40.6 & 35.4 & 34.2 & 30.3 \\
\hline Collaborative process & $4-8$ & 20.7 & 37.1 & 42.2 & 32.6 & 41.6 & 25.8 \\
\hline
\end{tabular}

Note. Average on frequency (\%): Positive responses include responses Strongly agree or Agree, neutral responses Neither agree nor disagree and Don't know, negative responses Disagree and Strongly disagree. 
Table 3.6: Students' perceptions of collaborative writing according to how important they assume digital tools to be in their future work as a teacher

\begin{tabular}{|c|c|c|c|c|c|c|c|}
\hline \multirow[b]{2}{*}{$\begin{array}{l}\text { Statement } \\
\text { category }\end{array}$} & \multirow[b]{2}{*}{$\begin{array}{c}\text { Statement } \\
n^{\circ}\end{array}$} & \multicolumn{3}{|c|}{$\begin{array}{c}\text { Medium, low, very low, } \\
\text { Don't know } \\
(n=51)\end{array}$} & \multicolumn{3}{|c|}{$\begin{array}{c}\text { High, very high } \\
(n=115)\end{array}$} \\
\hline & & Positive & Neutral & Negative & Positive & Neutral & Negative \\
\hline ollahorative tool & $1-3$ & 33.3 & 30.7 & 35.9 & 32.2 & 35.1 & 32.8 \\
\hline Collaborative process & $4-8$ & 20.0 & 42.4 & 37.6 & 32.5 & 39.1 & 28.3 \\
\hline
\end{tabular}

Note. Average on frequency (\%): Positive responses include responses Strongly agree or Agree, neutral responses Neither agree nor disagree and Don't know, negative responses Disagree and Strongly disagree.

\section{Educational settings}

Table 3.7 shows that responses from students at the main and satellite campus differed considerably. This may be due to different educational settings at the two campuses: each base group worked on a reflective and narrative task, one task at campus $\mathrm{C} 1$ and a comparable task at campus C2 (see section "Data Collection Methods"). While base groups of 5 to 7 students at campus C1 planned and elaborated their experiences being located at different schools, each group of 4 students at $\mathrm{C} 2$ was located at a single school during their practice.

Despite their larger size, the base groups at $\mathrm{C} 1$ indicated on average more positive and less negative perception, both according to the ease-of-use and effectiveness of the tool and of the collaborative climate of their writing situation.

As shown in Table 2, a large number of students indicated uncertainty about the value of the tool used and the collaborative writing. Also only 12 students from campus $\mathrm{C} 2$ have responded to the questionnaire. It therefore seems reasonable that a cautious analysis of these responses has to look into the students' description of their group work and line of actions. However, it is possible that base groups seeing each other at least in school hours were less motivated to use communication technology to collaborate than base groups working at different schools and at a distance. (See Appendix B, Table B7 for more details).

Table 3.7: Students' perceptions of collaborative writing in different educational settings

\begin{tabular}{|c|c|c|c|c|c|c|c|}
\hline \multirow[b]{2}{*}{$\begin{array}{l}\text { Statement } \\
\text { category }\end{array}$} & \multirow[b]{2}{*}{$\begin{array}{c}\text { Statement } \\
n^{\circ}\end{array}$} & \multicolumn{3}{|c|}{$\begin{array}{l}\text { Base groups of } 5-7 \text { at } \mathrm{C} 1 \text {, } \\
\text { spread to different schools } \\
\qquad(n=154)\end{array}$} & \multicolumn{3}{|c|}{$\begin{array}{l}\text { Base groups of } 4 \text { at } \mathrm{C} 2, \\
\text { gathered at same school } \\
(n=12)\end{array}$} \\
\hline & & Positive & Neutral & Negative & Positive & Neutral & $\overline{\text { Negative }}$ \\
\hline & $1-3$ & 33.5 & 33.8 & 32.7 & 19.4 & 33.3 & 47.2 \\
\hline Collaborative process & $4-8$ & 29.4 & 40.1 & 30.5 & 20.0 & 40.0 & 40.0 \\
\hline
\end{tabular}

Note. Average on frequency (\%): Positive responses include responses Strongly agree or Agree, neutral responses Neither agree nor disagree and Don't know, negative responses Disagree and Strongly disagree. $\mathrm{C} 1$ = main campus; $\mathrm{C} 2$ = satellite campus.

\section{Collaborative tools}

Table 3.8 show that students using GD tended to be considerably more positive regarding the collaborative tool (45.1\% / 29.3\%) and less negative regarding the process than those using EP $(25.5 \% / 32.6 \%)$, even though EP supposedly is easier to use. The explanation could be that EP 
was periodically unavailable during the students' work period. This is substantiated by the fact that only $10.6 \%$ of the students using EP agreed or strongly agreed to that the tool always worked as it should, in contrast to $41.2 \%$ of the students using GD. (See Appendix B, Table B8 for more details).

Table 3.8: Students' perceptions of collaborative writing according to tool used

\begin{tabular}{|c|c|c|c|c|c|c|c|}
\hline \multirow[b]{2}{*}{$\begin{array}{l}\text { Statement } \\
\text { category }\end{array}$} & \multirow[b]{2}{*}{$\begin{array}{c}\text { Statement } \\
n^{0}\end{array}$} & \multicolumn{3}{|c|}{$\begin{array}{l}\text { EtherPad } \\
(n=132)\end{array}$} & \multicolumn{3}{|c|}{$\begin{array}{c}\text { Google Docs } \\
(n=34)\end{array}$} \\
\hline & & Positive & Neutral & Negative & Positive & Neutral & Negative \\
\hline Collaborative tool & $1-3$ & 29.3 & 34.6 & 36.1 & 45.1 & 30.4 & 24.5 \\
\hline Collaborative process & $4-8$ & 28.2 & 39.2 & 32.6 & 30.6 & 43.5 & 25.9 \\
\hline
\end{tabular}

Note. Average on frequency (\%): Positive responses include responses Strongly agree or Agree, neutral responses Neither agree nor disagree and Don't know, negative responses Disagree and Strongly disagree.

\section{Limitations}

The limitations of the work are concerned with five issues: type of sample, validity and reliability, confidentiality, level of experiment control, and time considerations.

First, the study was conducted with a small convenience sample, with participants from one university only, and thus may not well cover the perceptions of the total population of beginner education students. While this should not invalidate the initial results, readers need to be aware of this limitation and consider the results of the study with some degree of caution. Replication studies with a larger population may confirm or question these early research results.

The second limitation is concerned with reliability and validity issues. Reliability refers to the extent to which the research results are consistent over time and an accurate representation of the population and if the results can be reproduced under similar circumstances using a similar methodology (Hardy \& Bryman, 2004). To achieve a high degree of reliability, it is important to be aware of the conditions and circumstances under which the study is carried out and the factors that may influence the results of the study. Reliability is also enhanced by an accurate description of the methodology being used so that it can be reused to produce similar results. High reliability is ensured only if these conditions are fulfilled, if used again in similar circumstances.

Two validity issues are concerned with the case study: measurement validity and external validity (Bryman, 2004; Hardy \& Bryman, 2004). Measurement validity is associated with the extent to which the data collection methods indicate what they are intended to measure. Survey questionnaires alone cannot accurately measure the students' perceptions of Web 2.0 technologies, but a higher degree of measurement validity is ensured through the use of qualitative data collection methods and their triangulation with survey questionnaires. External validity is concerned with the question of whether the results of the case can be generalized beyond the two campuses. Clearly, the case study cannot be generalized to other campuses because it is not known to which extent the students are representative for a larger population.

Third, limitations may arise from respondents not being anonymous because it is possible to link the answers to the students' name for university staff. Openness may impact the results. Not being anonymous may turn out at least two ways: students may complete the questionnaire with diligence, or they may avoid giving purely critical answers.

Fourth, freedom of how to use the collaborative writing tools during the group tasks caused a relatively low-level experimental control with the students' utilization of the tools. The qualitative 
data of the project will reveal more about, i.e., the conditions under which the students worked together in their respective groups, the quality of their collaboration, their task awareness, and the degree of reflection during their work. These important details may affect the results, but are not considered in this paper.

Fifth, reopening the surveys after the initial period, issuing reminders, and making special arrangements to increase the number of respondents may have produced some less serious responses.

\section{Conclusions and Future Work}

The goal of this work was to use a case study to assess education students' perceptions of collaborative work by means of survey questionnaires. More specifically, the aim was to assess whether GD and EP can support collaborative writing among students according to various parameters such as age, gender, students' digital competence, educational setting, and tool used.

Given this background, the main strength of this study is its contribution to the literature on the use of GD and EP as collaborative writing tools. As previously noted, little has been done to determine the extent to which their use has any impact on student collaborative subject work in higher education settings. This preliminary study offers something to begin filling that void. It provides a theoretical framework to inform the study about the relationships between collaborative learning theories and collaborative writing tools and how they influence each other. Furthermore this study offers a preliminary valuation of a training approach designed to help education students, with no prior training, get acquainted with collaborative tools and develop skills and competencies in implementation in educational tasks.

The case study allowed the investigation of the research questions and hypotheses by means of survey questionnaires. The results have been analyzed using a statistical analysis method based on frequency distributions. Frequencies alone cannot provide sufficient evidence that collaborative tools are easy-to-use, effective, enhance motivation, and increase collaboration, but they provide an overall picture of the students' subjective perceptions within a particular educational setting. Even though it is not possible to gain new insights that would be generalizable beyond the student population without an analysis of data collected by qualitative methods, it is possible to draw some conclusions about students' preferences, motivations, and ways of using the collaborative tools.

Firstly, the results seem to confirm the hypothesis that students with high digital competence and a positive attitude towards digital tools are more positive than average and that gender does not play any particular role. As for younger students being more positive than older, the population of older students was so low that no conclusion can be drawn. The work does not validate the hypothesis that EP-users are more positive than GD-users, since EP is considered as easier to use than GD. This may be explained by EP being unavailable for some time during the students' collaborative writing period.

Secondly, the results reveal that only $13.9 \%$ of the students were motivated to use the tools for collaboration. Additionally, only a minority of the students (15.7\%) reported that the quality of collaboration in the group increased with use of the tools. Likewise, the tools did not work as expected for most students (70.5\%). Regarding the collaborative writing process, no definitive conclusions could be drawn from the results. The results also reflect students' positive experiences with collaborative writing, e.g., forty-seven percent of the students liked to comment and edit others contributions to group work. Even though these results are consistent with some research work in the field of Web 2.0 technologies (Dron, 2007; Grion \& Varisco, 2007; Luckin et al., 2009), they need to be considered with caution until a qualitative analysis of the students' writings is undertaken. 
Thirdly, the results pointed out, as indicated above, that the collaborative tools did not work as expected, since only $16.9 \%$ strongly agreed or agreed that the tools did not create technical problems. It follows from the survey that most students encountered a number of technical problems that hindered them from fully performing their collaborative writing tasks. Besides this, it appears that collaborative tools alone cannot fully support true collaborative writing, even though they are designed with elements that facilitate collaboration, e.g., chat-function, concurrent editing and writing. Of course, the problems encountered by the students are not exclusively limited to the technicalities of the tools because other factors may have played an important role in the way students used the tools, worked together, and collaborated, such as course content, the pedagogy being used, time consideration, tool familiarization and integration, prerequisite knowledge and skills, and institutional and administrative constraints.

Summarizing, although these preliminary results cannot be generalized to a larger group of students, and no definite conclusions can be drawn from the survey questionnaire about the usefulness and effectiveness of GD and EP for collaborative writing, the results cannot be underestimated since some results are consistent with the research literature. Hence, these results will be taken into account and triangulated with qualitative data to perform a more in-depth analysis of the capabilities of the tools to support collaborative writing. Then, it will be possible to develop a pedagogical model that helps to understand how education students perceive, work with, and use GD and EP to achieve educational goals. The model will also provide a better understanding of collaborative tools in terms of advantages, mode of work, affordances, potentialities, and limitations. Furthermore, the model will allow a more thorough evaluation of the theoretical framework and its potential capabilities to support collaborative learning and communities of practices in terms of active participation, group interaction, and construction of shared knowledge.

Future research consists of the qualitative evaluation of the students' comments to open endedquestions in the survey questionnaire, the students' collaborative essay papers, and their contributions to group work. It may also be important to examine the extent and quality of utilization of the tool for collaborative writing. Triangulation of the data collected may shed light on how they really perceived the effectiveness of GD and EP to support collaborative writing among students.

\section{References}

Ajjan, H., \& Hartshorne, R. (2008). Investigating faculty decisions to adopt Web 2.0 technologies: Theory and empirical tests. Internet \& Higher Education, 11(2), 71-80.

Baltzersen, R. K. (2010). Radical transparency: Open access as a key concept in wiki pedagogy. Australasian Journal of Educational Technology, 26(6), 791-809.

Bell, A. (2009). Exploring Web 2.0: Second generation internet tools - blogs, podcasts, wikis, networking, virtual worlds, and more. Georgetown, TX: Katy Crossing Press.

Blau, I., \& Caspi, A. (2009). What type of collaboration helps? Psychological ownership, perceived learning and outcome quality of collaboration using Google Docs. Proceedings of the Chais conference on instructional technologies research 2009: Learning in the technological era, pp. 48-55.

Bonk, C., Lee, M., Kim, N., \& Lin, M. (2009). The tensions of transformation in three cross-institutional wikibook projects. Internet \& Higher Education, 12(3/4), 126-135.

Brush, T., \& Saye, J. W. (2009). Strategies for preparing pre-service social studies teachers to integrate technology effectively: Models and practices. Contemporary Issues in Technology and Teacher Education, 9(1), 46-59.

Bryman, A. (2004). Social research methods (2nd ed.). Oxford: University Press. 
Buzzetto-More, N. (2010). Assessing the efficacy and effectiveness of an e-portfolio used for summative assessment. Interdisciplinary Journal of E-Learning and Learning Objects, 6, 61-85. Retrieved April 5, 2011, from http://www.ijello.org/Volume6/IJELLOv6p061-085Buzzetto691.pdf

Cattafi, R., \& Metzner, C. (2007). A didactic experience in collaborative learning. Issues in Informing Science and Information Technology, 4, 15-28. Retrieved March 11, 2011 from http://proceedings.informingscience.org/InSITE2007/IISITv4p015-028Catt351.pdf

Chu, S., Kennedy, D., \& Mak, M. (2009). MediaWiki and Google Docs as online collaborative tools for group project co-construction. Proceedings of the 2009 International Conference on Knowledge Management [CDROM]. Hong Kong, Dec 3-4, 2009.

Dron, J. (2007). Designing the undesignable: Social software and control. Educational Technology \& Society, 10(3), 60-71.

Dubé. L., Bourhis, A. \& Jacob, R. (2006). Towards a typology of virtual communities of practice. Interdisciplinary Journal of Information, Knowledge, and Management, 1, 69-93. Retrieved April 5, 2011, from http://www.ijikm.org/Volume1/IJIKMv1p069-093Dube.pdf

Elgort, I., Smith, A.G., \& Toland, J. (2008). Is wiki an effective platform for group course work? Australasian Journal of Educational Technology, 24(2), 195-210.

Erstad, O. (2009): Addressing the complexity of impact - A multilevel approach towards ICT in education. In F. Scheuermann \& F. Pedro (Eds.), Assessing the effects of ICT in education. Indicators, criteria and benchmarks for international comparisons (pp. 21-38). Luxembourg: Publications Office of the European Union.

EtherPad (2008). EtherPad: Really real time collaboration. Retrieved from http://ietherpad.com/

European Schoolnet. (2010). 2009 series of insight country reports. In A. Balantskat \& V. Garoia (Eds), 2009/2010 Insight Country Reports. Retrieved November 5, 2010, from http://insight.eun.org/ww/en/pub/insight/policy/policies/2009_country_reports.htm

Garner, S. (2010). Supporting the personal knowledge management of students with technology. Proceedings of Informing Science \& IT Education Conference (InSITE) 2010, pp. 237-246. Retrieved March 17, 2011, from http://proceedings.informingscience.org/InSITE2010/InSITE10p237-246Garner764.pdf

Google Docs (2008). Free web-based word processor, spreadsheet, presentation, and form which allow you share and collaborate online. Retrieved from http://docs.google.com

Grion, V., \& Varisco, B .M. (2007). Online collaboration for building a teacher professional identity. PsychNology Journal, 5(3), 271 - 284. Retrieved October 26, 2010, from www.psychnology.org

Hardy, M., \& Bryman, A. (Eds.). (2004) Handbook of data analysis. London: SAGE Publications.

Hoya, B. (2010). Google Docs, EtherPad, and then some: Word processing and collaboration in today's portable work environment. Texas Library Journal, 86(2), 60-62.

Jones, C., Ramanau, R., Cross, S., \& Healing, G. (2010). Net generation or digital natives: Is there a distinct new generation entering university? Computers \& Education, 54(3), 722-732.

Karasavvidis, I. (2010). Wiki uses in higher education: Exploring barriers to successful implementation. Interactive Learning Environments, 18(3), 219-231.

Kasemvilas, S., \& Olfman, L. (2009). Design alternatives for a MediaWiki to support collaborative writing. Journal of Information, Information Technology, and Organizations, 4, 87-106. Retrieved from http://jiito.org/articles/JIITOv4p087-106Kasemvilas.pdf

Kennedy, G., Judd, T. S., Churchward, A., Gray, K., \& Krause, K. (2008). First year students' experiences with technology: Are they really digital natives? Australasian Journal of Educational Technology, 24(1), 108-122. Retrieved November 24, 2010, from http://www.ascilite.org.au/ajet/ajet24/kennedy.pdf 
Kim, P. \&, Hong, J.-S., Bonk, C. \& Lim, G. (2009). Effects of group reflection variations in project-based learning integrated in a Web 2.0 learning space. Interactive Learning Environments, 1-17.

Kittle, P., \& Hicks, T. (2009). Transforming the group paper with collaborative online writing. Pedagogy: Critical Approaches to Teaching Literature, Language, Composition, and Culture, 9(3), 525-538.

Koohang, A., Riley, L., \& Smith, T. (2009). E-learning and constructivism: From theory to application. Interdisciplinary Journal of E-Learning and Learning Objects, 5, 91-109. Retrieved April 5, 2011, from http://www.ijello.org/Volume5/IJELLOv5p091-109Koohang655.pdf

Krebs, M., Schmidt, C., Henninger, M., Ludwig, M., \& Müller, W. (2010). Are wikis and weblogs an appropriate approach to foster collaboration, reflection and students' motivation? In N. Reynolds \& M. Turcsányi-Szabó (Eds.), IFIP advances in information and communication technology: Vol. 324. Key competencies in the knowledge society (pp. 200-209). Berlin: Springer.

Lamb, A., \& Johnson, L. (2010). Beyond Googling: Applying Google tools to inquiry-based learning. Teacher Librarian, 37(4), 83-86.

Lave, J., \& Wenger, E. (1998). Situated learning: Legitimate peripheral participation. New York: Cambridge University Press.

Luckin, R., Clark, W., Graber, R., Logan, K., Mee, A., \& Oliver, M. (2009). Do Web 2.0 tools really open the door to learning? Practices, perceptions and profiles of 11-16-year-old students. Learning, Media, and Technology, 34(2), 87-104.

Lipponen, L. (2002). Exploring foundations for computer-supported collaborative learning. In G. Stahl (Ed.), Computer support for collaborative learning: 2002. Foundations for a CSCL community (pp. 72-81). Hillsdale, NJ: Erlbaum.

Miles, V. C., McCarthy, J. C., Dix, A. J., Harrison, M. D. \& Monk, A. F. (1993). Reviewing designs for a synchronous-asynchronous group editing environment. In M. Sharples (Ed.). Computer supported collaborative writing (pp. 137-160). Berlin: Springer.

Norwegian Ministry of Education and Research. (2009). White paper on teacher education "The teacherthe role and the education". Report to the Storting No. 11 (2008-2009). Retrieved November 05, 2010, from http://www.regjeringen.no/upload/KD/Vedlegg/stortingsmeldinger/Teacher_Education_FactSheet.pdf

Parker, K. R., \& Chao, J. T. (2007). Wiki as a teaching tool. Interdisciplinary Journal of Knowledge and Learning Objects, 3, 57-72. Retrieved May 9, 2010, from: http://www.ijello.org/Volume3/IJKLOv3p057-072Parker284.pdf

Prensky, M. (2001). Digital natives, digital immigrants. On the Horizon, 9(5), 1-6.

Prensky, M. (2010). Teaching digital natives: Partnering for real learning. Thousand Oaks, Calif.: Corwin Press.

Pusey, P., \& Meiselwitz, G. (2009). Heuristics for implementation of wiki technology in higher education learning. In A. Ozok \& P. Zaphiris (Eds.), Lecture Notes in Computer Science: Vol. 5621.Online Communities and Social Computing (pp. 507-514). Berlin: Springer.

Rice, J. A. (2009). Devising collective knowledge for the technical writing classroom: A course-based approach to using Web 2.0 writing technologies in collaborative work tutorial. IEEE Transactions on professional Communications, 52(3), 303-315.

Rienzo, T., \& Han, B. (2009). Microsoft or Google Web 2.0 tools for course management. Journal of Information Systems Education, 20(2), 123-128.

Søby, M. (2009). Norway country report on ICT in education. Retrieved November 5, 2010, from http://cms.eun.org/shared/data/pdf/cr_norway 2009 final proofread 2 columns.pdf

Su, F., \& Beaumont, C. (2010). Evaluating the use of a wiki for collaborative learning. Innovations in Education \& Teaching International, 47(4), 417-431. 
Trentin, G. (2009). Using a wiki to evaluate individual contribution to a collaborative learning project. Journal of Computers Assisted Learning, 25(1), 43-55.

Tsoi, M. F. (2010). Supporting productive integration of Web 2.0-mediated collaboration. In N. Reynolds and M. Turcsányi-Szabó (Eds.), KCKS 2010, IFIP AICT 324, pp. 401-411. IFIP International Federation for Information Processing.

Tømte, C., Hovdhaugen, E., \& Solum, N.H. (2009). ICT in initial teacher training - Norway (Country Report/Case Study). Retrieved November 5, 2010, from http://www.oecd.org/dataoecd/6/61/45128319.pdf

Vygotsky, L. (1978). Mind in society. Cambridge, MA: Harvard University Press.

Wenger, E. (1998). Communities of practice: Learning, meaning, and identity. New York: Cambridge University Press.

\section{Appendix A}

Table A1: Skill levels assigned to computer tasks

\begin{tabular}{lcllc}
\hline Activity & $\begin{array}{c}\text { Skill } \\
\text { level }\end{array}$ & & Activity & $\begin{array}{r}\text { Skill } \\
\text { level }\end{array}$ \\
\cline { 1 - 2 } \cline { 5 - 5 } Uses presentation tools & 1 & & Uploads files & 3 \\
Uses word processor & 1 & & Uploads to LMS (Fronter, It's Learning) & 3 \\
Searches the Internet & 2 & & Posts on own blog & 4 \\
Searches Wikipedia & 2 & & Posts on own Web page & 4 \\
Sends instant messages (Chat, Messenger) & 2 & & Builds Web pages from scratch (HTML) & 5 \\
Uses e-mail & 2 & & Edits images & 5 \\
Shops on the Internet & 3 & Illustrates texts with images/videos & 5 \\
\hline
\end{tabular}

Table A2: Values assigned to frequency of performing a computer task

\begin{tabular}{lcllc}
\hline Frequency & Value & & Frequency & Value \\
\cline { 1 - 2 } \cline { 5 - 6 } Don't know & 0 & & Monthly & 5 \\
Never & 0 & & Weekly & 6 \\
Less than monthly & 3 & & Daily & 7 \\
\hline
\end{tabular}

Table A3: Classifying digital competence

\begin{tabular}{|c|c|c|c|}
\hline Largest product & Digital competence & Largest product & Digital competence \\
\hline $0-13$ & Very low & $28-34$ & High \\
\hline $14-20$ & Low & 35 & Very high \\
\hline $21-27$ & Medium & & \\
\hline
\end{tabular}




\section{Appendix B}

Table B1: Students' perceptions of collaborative writing according to gender

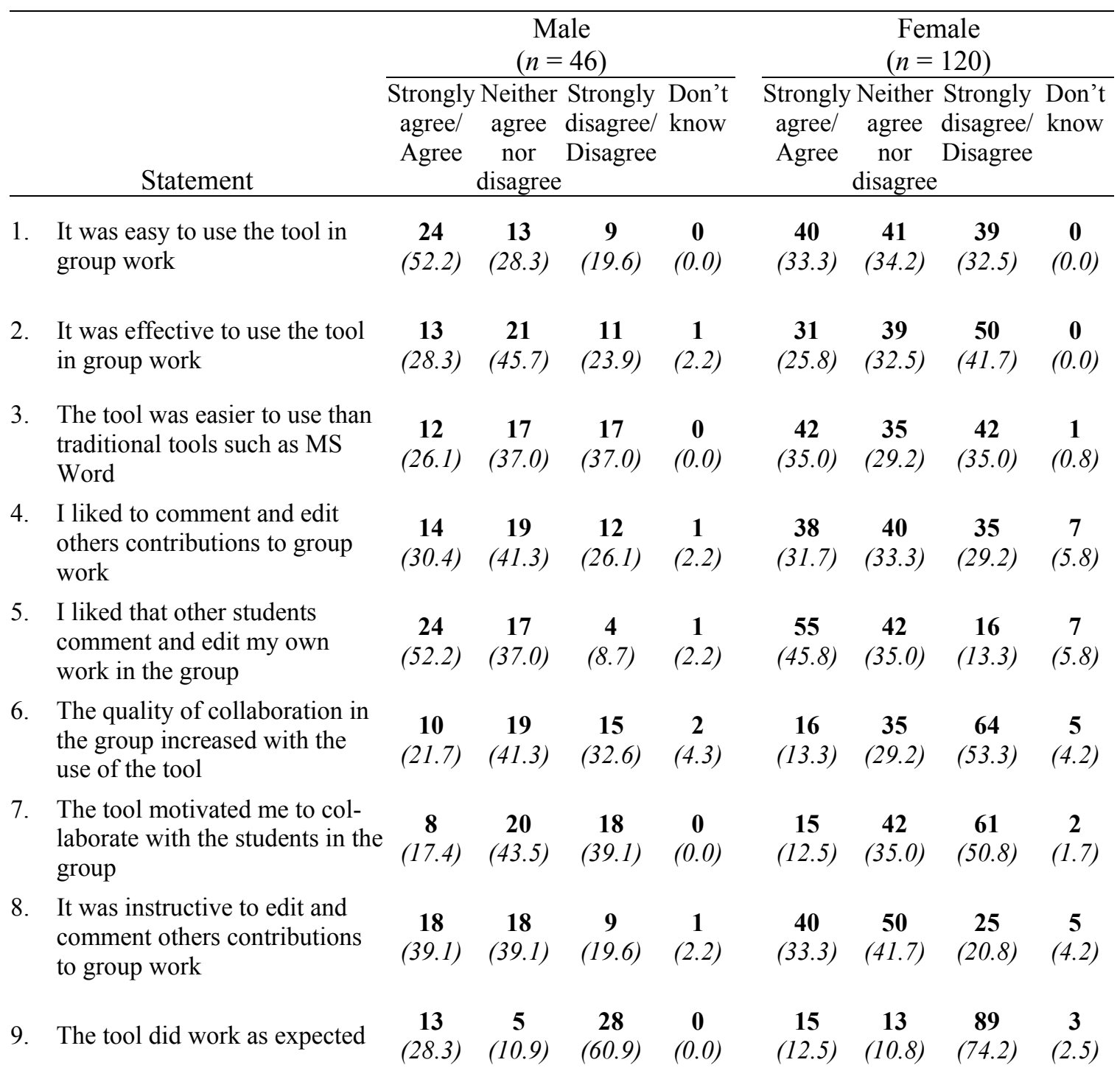

Note. Frequency of responses is in boldface; percentage is italicized and parenthesized. 
Table B2: Students' perceptions of collaborative writing according to age

\begin{tabular}{|c|c|c|c|c|c|c|c|c|c|}
\hline \multirow{2}{*}{\multicolumn{2}{|c|}{ Statement }} & \multicolumn{4}{|c|}{$\begin{array}{l}\text { Aged 19-27 } \\
(n=149)\end{array}$} & \multicolumn{4}{|c|}{$\begin{array}{c}\text { Aged 28-44 } \\
(n=17) \\
\end{array}$} \\
\hline & & $\begin{array}{c}\text { Strongly } \\
\text { agree/ } \\
\text { Agree }\end{array}$ & $\begin{array}{l}\text { Neither } \\
\text { agree } \\
\text { nor } \\
\text { disagree }\end{array}$ & $\begin{array}{l}\text { Strongly } \\
\text { disagree/ } \\
\text { Disagree }\end{array}$ & $\begin{array}{l}\text { Don't } \\
\text { know }\end{array}$ & $\begin{array}{c}\begin{array}{c}\text { Strongly } \\
\text { agree/ } \\
\text { Agree }\end{array} \\
\end{array}$ & $\begin{array}{l}\text { Neither } \\
\text { agree } \\
\text { nor } \\
\text { disagree } \\
\end{array}$ & $\begin{array}{l}\text { Strongly } \\
\text { disagree/ } \\
\text { Disagree }\end{array}$ & $\begin{array}{l}\text { Don't } \\
\text { know }\end{array}$ \\
\hline 1. & $\begin{array}{l}\text { It was easy to use the tool in } \\
\text { group work }\end{array}$ & $\begin{array}{c}\mathbf{5 6} \\
(37.6)\end{array}$ & $\begin{array}{c}\mathbf{5 0} \\
(33.6)\end{array}$ & $\begin{array}{c}\mathbf{4 3} \\
(28.9)\end{array}$ & $\begin{array}{c}\mathbf{0} \\
(0.0)\end{array}$ & $\begin{array}{c}\mathbf{8} \\
(47.1)\end{array}$ & $\begin{array}{c}\mathbf{4} \\
(23.5)\end{array}$ & $\begin{array}{c}\mathbf{5} \\
(29.4)\end{array}$ & $\begin{array}{c}\mathbf{0} \\
(0.0)\end{array}$ \\
\hline 2. & $\begin{array}{l}\text { It was effective to use the tool } \\
\text { in group work }\end{array}$ & $\begin{array}{c}37 \\
(24.8)\end{array}$ & $\begin{array}{c}\mathbf{5 4} \\
(36.9)\end{array}$ & $\begin{array}{c}\mathbf{5 7} \\
(38.3)\end{array}$ & $\begin{array}{c}1 \\
(0.7)\end{array}$ & $\begin{array}{c}7 \\
(41.2)\end{array}$ & $\begin{array}{c}\mathbf{6} \\
(35.3)\end{array}$ & $\begin{array}{c}\mathbf{4} \\
(23.5)\end{array}$ & $\begin{array}{c}\mathbf{0} \\
(0.0)\end{array}$ \\
\hline 3. & $\begin{array}{l}\text { The tool was easier to use than } \\
\text { traditional tools such as MS } \\
\text { Word }\end{array}$ & $\begin{array}{c}49 \\
(32.9)\end{array}$ & $\begin{array}{c}44 \\
(30.2)\end{array}$ & $\begin{array}{c}\mathbf{5 5} \\
(36.9)\end{array}$ & $\begin{array}{c}1 \\
(0.7)\end{array}$ & $\begin{array}{c}\mathbf{5} \\
(29.4)\end{array}$ & $\begin{array}{c}8 \\
(47.1)\end{array}$ & $\begin{array}{c}\mathbf{4} \\
(23.5)\end{array}$ & $\begin{array}{c}\mathbf{0} \\
(0.0)\end{array}$ \\
\hline 4. & $\begin{array}{l}\text { I liked to comment and edit } \\
\text { others contributions to group } \\
\text { work }\end{array}$ & $\begin{array}{c}49 \\
(32.9)\end{array}$ & $\begin{array}{c}\mathbf{5 3} \\
(39.6)\end{array}$ & $\begin{array}{c}\mathbf{4 1} \\
(27.5)\end{array}$ & $\begin{array}{c}\mathbf{6} \\
(4.0)\end{array}$ & $\begin{array}{c}\mathbf{3} \\
(17.6)\end{array}$ & $\begin{array}{c}\mathbf{6} \\
(47.1)\end{array}$ & $\begin{array}{c}\mathbf{6} \\
(35.3)\end{array}$ & $\begin{array}{c}\mathbf{2} \\
(11.8)\end{array}$ \\
\hline 5. & $\begin{array}{l}\text { I liked that other students } \\
\text { comment and edit my own } \\
\text { work in the group }\end{array}$ & $\begin{array}{c}73 \\
(49.0)\end{array}$ & $\begin{array}{c}\mathbf{5 1} \\
(38.9)\end{array}$ & $\begin{array}{c}\mathbf{1 8} \\
(12.1)\end{array}$ & $\begin{array}{c}7 \\
(4.7)\end{array}$ & $\begin{array}{c}\mathbf{6} \\
(35.3)\end{array}$ & $\begin{array}{c}\mathbf{8} \\
(52.9)\end{array}$ & $\begin{array}{c}\mathbf{2} \\
(11.8)\end{array}$ & $\begin{array}{c}1 \\
(5.9)\end{array}$ \\
\hline 6. & $\begin{array}{l}\text { The quality of collaboration in } \\
\text { the group increased with the } \\
\text { use of the tool }\end{array}$ & $\begin{array}{c}\mathbf{2 4} \\
(16.1)\end{array}$ & $\begin{array}{c}49 \\
(36.9)\end{array}$ & $\begin{array}{c}\mathbf{7 0} \\
(47.0)\end{array}$ & $\begin{array}{c}\mathbf{6} \\
(4.0)\end{array}$ & $\begin{array}{c}\mathbf{2} \\
(11.8)\end{array}$ & $\begin{array}{c}\mathbf{5} \\
(35.3)\end{array}$ & $\begin{array}{c}9 \\
(52.9)\end{array}$ & $\begin{array}{c}1 \\
(5.9)\end{array}$ \\
\hline 7. & $\begin{array}{l}\text { The tool motivated me to col- } \\
\text { laborate with the students in the } \\
\text { group }\end{array}$ & $\begin{array}{c}\mathbf{2 0} \\
(13.4)\end{array}$ & $\begin{array}{c}\mathbf{5 5} \\
(38.3)\end{array}$ & $\begin{array}{c}72 \\
(48.3)\end{array}$ & $\begin{array}{c}\mathbf{2} \\
(1.3)\end{array}$ & $\begin{array}{c}\mathbf{3} \\
(17.6)\end{array}$ & $\begin{array}{c}7 \\
(41.2)\end{array}$ & $\begin{array}{c}7 \\
(41.2)\end{array}$ & $\begin{array}{c}\mathbf{0} \\
(0.0)\end{array}$ \\
\hline 8. & $\begin{array}{l}\text { It was instructive to edit and } \\
\text { comment others contributions } \\
\text { to group work }\end{array}$ & $\begin{array}{c}\mathbf{5 3} \\
(35.6)\end{array}$ & $\begin{array}{c}\mathbf{5 9} \\
(43.0)\end{array}$ & $\begin{array}{c}32 \\
(21.5)\end{array}$ & $\begin{array}{c}\mathbf{5} \\
(3.4)\end{array}$ & $\begin{array}{c}\mathbf{5} \\
(29.4)\end{array}$ & $\begin{array}{c}9 \\
(58.8)\end{array}$ & $\begin{array}{c}\mathbf{2} \\
(11.8)\end{array}$ & $\begin{array}{c}\mathbf{1} \\
(5.9)\end{array}$ \\
\hline 9. & The tool did work as expected & $\begin{array}{c}\mathbf{2 6} \\
(17.4)\end{array}$ & $\begin{array}{c}\mathbf{1 5} \\
(12.1)\end{array}$ & $\begin{array}{c}\mathbf{1 0 5} \\
(70.5)\end{array}$ & $\begin{array}{c}3 \\
(2.0)\end{array}$ & $\begin{array}{c}\mathbf{2} \\
(11.8)\end{array}$ & $\begin{array}{c}\mathbf{3} \\
(17.6)\end{array}$ & $\begin{array}{c}12 \\
(70.6)\end{array}$ & $\begin{array}{c}\mathbf{0} \\
(0.0)\end{array}$ \\
\hline
\end{tabular}

Note. Frequency of responses is in boldface; percentage is italicized and parenthesized. 


\section{Table B3: Students' perceptions of collaborative writing according to own perception of} digital competence

\begin{tabular}{|c|c|c|c|c|c|c|c|c|c|}
\hline \multirow{2}{*}{\multicolumn{2}{|c|}{ Statement }} & \multicolumn{4}{|c|}{$\begin{array}{c}\text { Medium, low, very low, } \\
\text { Don't know } \\
(n=54) \\
\end{array}$} & \multicolumn{4}{|c|}{$\begin{array}{l}\text { High or very high } \\
(n=112)\end{array}$} \\
\hline & & $\begin{array}{l}\text { Strongly } \\
\text { agree/ } \\
\text { Agree }\end{array}$ & $\begin{array}{l}\text { Neither } \\
\text { agree } \\
\text { nor } \\
\text { disagree }\end{array}$ & $\begin{array}{l}\text { Strongly } \\
\text { disagree/ } \\
\text { Disagree }\end{array}$ & $\begin{array}{l}\text { Don't } \\
\text { know }\end{array}$ & $\begin{array}{l}\text { Strongly } \\
\text { agree/ } \\
\text { Agree }\end{array}$ & $\begin{array}{l}\text { Neither } \\
\text { agree } \\
\text { nor } \\
\text { disagree }\end{array}$ & $\begin{array}{l}\text { Strongly } \\
\text { disagree/ } \\
\text { Disagree }\end{array}$ & $\begin{array}{l}\text { Don't } \\
\text { know }\end{array}$ \\
\hline 1. & $\begin{array}{l}\text { It was easy to use the tool in } \\
\text { group work }\end{array}$ & $\begin{array}{c}\mathbf{2 1} \\
(38.9)\end{array}$ & $\begin{array}{c}17 \\
(31.5)\end{array}$ & $\begin{array}{c}\mathbf{1 6} \\
(29.6)\end{array}$ & $\begin{array}{c}\mathbf{0} \\
(0.0)\end{array}$ & $\begin{array}{c}\mathbf{4 3} \\
(38.4)\end{array}$ & $\begin{array}{c}37 \\
(33.0)\end{array}$ & $\begin{array}{c}32 \\
(28.6)\end{array}$ & $\begin{array}{c}\mathbf{0} \\
(0.0)\end{array}$ \\
\hline 2. & $\begin{array}{l}\text { It was effective to use the tool } \\
\text { in group work }\end{array}$ & $\begin{array}{c}\mathbf{1 4} \\
(25.9)\end{array}$ & $\begin{array}{c}21 \\
(38.9)\end{array}$ & $\begin{array}{c}\mathbf{1 9} \\
(35.2)\end{array}$ & $\begin{array}{c}\mathbf{0} \\
(0.0)\end{array}$ & $\begin{array}{c}30 \\
(26.8)\end{array}$ & $\begin{array}{c}39 \\
(34.8)\end{array}$ & $\begin{array}{c}\mathbf{4 2} \\
(37.5)\end{array}$ & $\begin{array}{c}1 \\
(0.9)\end{array}$ \\
\hline 3. & $\begin{array}{l}\text { The tool was easier to use than } \\
\text { traditional tools such as MS } \\
\text { Word }\end{array}$ & $\begin{array}{c}19 \\
(35.2)\end{array}$ & $\begin{array}{c}19 \\
(35.2)\end{array}$ & $\begin{array}{c}\mathbf{1 5} \\
(27.8)\end{array}$ & $\begin{array}{c}1 \\
(1.9)\end{array}$ & $\begin{array}{c}35 \\
(31.3)\end{array}$ & $\begin{array}{c}33 \\
(29.5)\end{array}$ & $\begin{array}{c}44 \\
(39.3)\end{array}$ & $\begin{array}{c}\mathbf{0} \\
(0.0)\end{array}$ \\
\hline 4. & $\begin{array}{l}\text { I liked to comment and edit } \\
\text { others contributions to group } \\
\text { work }\end{array}$ & $\begin{array}{c}\mathbf{1 5} \\
(27.8)\end{array}$ & $\begin{array}{c}\mathbf{1 7} \\
(31.5)\end{array}$ & $\begin{array}{c}17 \\
(31.5)\end{array}$ & $\begin{array}{c}\mathbf{5} \\
(9.3)\end{array}$ & $\begin{array}{c}37 \\
(33.0)\end{array}$ & $\begin{array}{c}\mathbf{4 2} \\
(37.5)\end{array}$ & $\begin{array}{c}30 \\
(26.8)\end{array}$ & $\begin{array}{c}3 \\
(2.7)\end{array}$ \\
\hline 5. & $\begin{array}{l}\text { I liked that other students } \\
\text { comment and edit my own } \\
\text { work in the group }\end{array}$ & $\begin{array}{c}\mathbf{2 5} \\
(46.3)\end{array}$ & $\begin{array}{c}19 \\
(35.2)\end{array}$ & $\begin{array}{c}\mathbf{6} \\
(11.1)\end{array}$ & $\begin{array}{c}4 \\
(7.4)\end{array}$ & $\begin{array}{c}\mathbf{5 4} \\
(48.2)\end{array}$ & $\begin{array}{c}\mathbf{4 0} \\
(35.7)\end{array}$ & $\begin{array}{c}\mathbf{1 4} \\
(12.5)\end{array}$ & $\begin{array}{c}4 \\
(3.6)\end{array}$ \\
\hline 6. & $\begin{array}{l}\text { The quality of collaboration in } \\
\text { the group increased with the } \\
\text { use of the tool }\end{array}$ & $\begin{array}{c}\mathbf{8} \\
(14.8)\end{array}$ & $\begin{array}{c}\mathbf{1 5} \\
(27.8)\end{array}$ & $\begin{array}{c}27 \\
(50.0)\end{array}$ & $\begin{array}{c}4 \\
(7.4)\end{array}$ & $\begin{array}{c}\mathbf{1 8} \\
(16.1)\end{array}$ & $\begin{array}{c}39 \\
(34.8)\end{array}$ & $\begin{array}{c}\mathbf{5 2} \\
(46.4)\end{array}$ & $\begin{array}{c}\mathbf{3} \\
(2.7)\end{array}$ \\
\hline 7. & $\begin{array}{l}\text { The tool motivated me to col- } \\
\text { laborate with the students in the } \\
\text { group }\end{array}$ & $\begin{array}{c}7 \\
(13.0)\end{array}$ & $\begin{array}{c}19 \\
(35.2)\end{array}$ & $\begin{array}{c}\mathbf{2 6} \\
(48.1)\end{array}$ & $\begin{array}{c}\mathbf{2} \\
(3.7)\end{array}$ & $\begin{array}{c}\mathbf{1 6} \\
(14.3)\end{array}$ & $\begin{array}{c}\mathbf{4 3} \\
(38.4)\end{array}$ & $\begin{array}{c}\mathbf{5 3} \\
(47.3)\end{array}$ & $\begin{array}{c}\mathbf{0} \\
(0.0)\end{array}$ \\
\hline 8. & $\begin{array}{l}\text { It was instructive to edit and } \\
\text { comment others contributions } \\
\text { to group work }\end{array}$ & $\begin{array}{c}\mathbf{1 5} \\
(27.8)\end{array}$ & $\begin{array}{c}\mathbf{2 6} \\
(48.1)\end{array}$ & $\begin{array}{c}\mathbf{1 0} \\
(18.5)\end{array}$ & $\begin{array}{c}3 \\
(5.6)\end{array}$ & $\begin{array}{c}\mathbf{4 3} \\
(38.4)\end{array}$ & $\begin{array}{c}42 \\
(37.5)\end{array}$ & $\begin{array}{c}\mathbf{2 4} \\
(21.4)\end{array}$ & $\begin{array}{c}\mathbf{3} \\
(2.7)\end{array}$ \\
\hline 9. & The tool did work as expected & $\begin{array}{c}\mathbf{1 0} \\
(18.5)\end{array}$ & $\begin{array}{c}\mathbf{5} \\
(9.3)\end{array}$ & $\begin{array}{c}39 \\
(72.2)\end{array}$ & $\begin{array}{c}\mathbf{0} \\
(0.0)\end{array}$ & $\begin{array}{c}\mathbf{1 8} \\
(16.1)\end{array}$ & $\begin{array}{c}\mathbf{1 3} \\
(11.6)\end{array}$ & $\begin{array}{c}\mathbf{7 8} \\
(69.6)\end{array}$ & $\begin{array}{c}\mathbf{3} \\
(2.7)\end{array}$ \\
\hline
\end{tabular}

Note. Frequency of responses is in boldface; percentage is italicized and parenthesized. 
Table B4: Students' perceptions of collaborative writing according to estimated digital competence

\begin{tabular}{|c|c|c|c|c|c|c|c|c|c|}
\hline \multirow{2}{*}{\multicolumn{2}{|c|}{ Statement }} & \multicolumn{4}{|c|}{$\begin{array}{c}\text { Medium, low, very low, } \\
\text { Don't know } \\
(n=122)\end{array}$} & \multicolumn{4}{|c|}{$\begin{array}{l}\text { High or very high } \\
\qquad(n=44)\end{array}$} \\
\hline & & $\begin{array}{l}\text { Strongly } \\
\text { agree/ } \\
\text { Agree }\end{array}$ & $\begin{array}{l}\text { Neither } \\
\text { agree } \\
\text { nor } \\
\text { disagree }\end{array}$ & $\begin{array}{l}\text { Strongly } \\
\text { disagree/ } \\
\text { Disagree }\end{array}$ & $\begin{array}{l}\text { Don't } \\
\text { know }\end{array}$ & $\begin{array}{l}\text { Strongly } \\
\text { agree/ } \\
\text { Agree }\end{array}$ & $\begin{array}{l}\text { Neither } \\
\text { agree } \\
\text { nor } \\
\text { disagree }\end{array}$ & $\begin{array}{l}\text { Strongly } \\
\text { disagree/ } \\
\text { Disagree }\end{array}$ & $\begin{array}{l}\text { Don't } \\
\text { know }\end{array}$ \\
\hline 1. & $\begin{array}{l}\text { It was easy to use the tool in } \\
\text { group work }\end{array}$ & $\begin{array}{c}42 \\
(34.4)\end{array}$ & $\begin{array}{c}38 \\
(31.1)\end{array}$ & $\begin{array}{c}\mathbf{4 2} \\
(34.4)\end{array}$ & $\begin{array}{c}\mathbf{0} \\
(0.0)\end{array}$ & $\begin{array}{c}\mathbf{2 2} \\
(50.0)\end{array}$ & $\begin{array}{c}16 \\
(36.4)\end{array}$ & $\begin{array}{c}\mathbf{6} \\
(13.6)\end{array}$ & $\begin{array}{c}\mathbf{0} \\
(0.0)\end{array}$ \\
\hline 2. & $\begin{array}{l}\text { It was effective to use the tool } \\
\text { in group work }\end{array}$ & $\begin{array}{c}\mathbf{2 7} \\
(22.1)\end{array}$ & $\begin{array}{c}\mathbf{4 8} \\
(39.3)\end{array}$ & $\begin{array}{c}46 \\
(37.7)\end{array}$ & $\begin{array}{c}\mathbf{1} \\
(0.8)\end{array}$ & $\begin{array}{c}17 \\
(38.6)\end{array}$ & $\begin{array}{c}12 \\
(27.3)\end{array}$ & $\begin{array}{c}15 \\
(34.1)\end{array}$ & $\begin{array}{c}\mathbf{0} \\
(0.0)\end{array}$ \\
\hline 3. & $\begin{array}{l}\text { The tool was easier to use than } \\
\text { traditional tools such as MS } \\
\text { Word }\end{array}$ & $\begin{array}{c}\mathbf{3 8} \\
(31.1)\end{array}$ & $\begin{array}{c}37 \\
(30.3)\end{array}$ & $\begin{array}{c}\mathbf{4 7} \\
(38.5)\end{array}$ & $\begin{array}{c}\mathbf{0} \\
(0.0)\end{array}$ & $\begin{array}{c}16 \\
(36.4)\end{array}$ & $\begin{array}{c}\mathbf{1 5} \\
(34.1)\end{array}$ & $\begin{array}{c}\mathbf{1 2} \\
(27.3)\end{array}$ & $\begin{array}{c}\mathbf{1} \\
(2.3)\end{array}$ \\
\hline 4. & $\begin{array}{l}\text { I liked to comment and edit } \\
\text { others contributions to group } \\
\text { work }\end{array}$ & $\begin{array}{c}\mathbf{3 5} \\
(28.7)\end{array}$ & $\begin{array}{c}\mathbf{4 4} \\
(36.1)\end{array}$ & $\begin{array}{c}\mathbf{3 6} \\
(29.5)\end{array}$ & $\begin{array}{c}7 \\
(5.7)\end{array}$ & $\begin{array}{c}17 \\
(38.6)\end{array}$ & $\begin{array}{c}15 \\
(34.1)\end{array}$ & $\begin{array}{c}11 \\
(25.0)\end{array}$ & $\begin{array}{c}\mathbf{1} \\
(2.3)\end{array}$ \\
\hline 5. & $\begin{array}{l}\text { I liked that other students } \\
\text { comment and edit my own } \\
\text { work in the group }\end{array}$ & $\begin{array}{c}\mathbf{5 6} \\
(45.9)\end{array}$ & $\begin{array}{c}\mathbf{4 3} \\
(35.2)\end{array}$ & $\begin{array}{c}\mathbf{1 6} \\
(13.1)\end{array}$ & $\begin{array}{c}7 \\
(5.7)\end{array}$ & $\begin{array}{c}\mathbf{2 3} \\
(52.3)\end{array}$ & $\begin{array}{c}16 \\
(36.4)\end{array}$ & $\begin{array}{c}4 \\
(9.1)\end{array}$ & $\begin{array}{c}\mathbf{1} \\
(2.3)\end{array}$ \\
\hline 6. & $\begin{array}{l}\text { The quality of collaboration in } \\
\text { the group increased with the } \\
\text { use of the tool }\end{array}$ & $\begin{array}{c}19 \\
(15.6)\end{array}$ & $\begin{array}{c}\mathbf{3 5} \\
(28.7)\end{array}$ & $\begin{array}{c}\mathbf{6 2} \\
(50.8)\end{array}$ & $\begin{array}{c}\mathbf{6} \\
(4.9)\end{array}$ & $\begin{array}{c}7 \\
(15.9)\end{array}$ & $\begin{array}{c}19 \\
(43.2)\end{array}$ & $\begin{array}{c}17 \\
(38.6)\end{array}$ & $\begin{array}{c}\mathbf{1} \\
(2.3)\end{array}$ \\
\hline 7. & $\begin{array}{l}\text { The tool motivated me to col- } \\
\text { laborate with the students in the } \\
\text { group }\end{array}$ & $\begin{array}{c}\mathbf{1 7} \\
(13.9)\end{array}$ & $\begin{array}{c}\mathbf{4 3} \\
(35.2)\end{array}$ & $\begin{array}{c}\mathbf{6 1} \\
(50.0)\end{array}$ & $\begin{array}{c}\mathbf{1} \\
(0.8)\end{array}$ & $\begin{array}{c}\mathbf{6} \\
(13.6)\end{array}$ & $\begin{array}{c}19 \\
(43.2)\end{array}$ & $\begin{array}{c}\mathbf{1 8} \\
(40.9)\end{array}$ & $\begin{array}{c}\mathbf{1} \\
(2.3)\end{array}$ \\
\hline 8. & $\begin{array}{l}\text { It was instructive to edit and } \\
\text { comment others contributions } \\
\text { to group work }\end{array}$ & $\begin{array}{c}39 \\
(32.0)\end{array}$ & $\begin{array}{c}\mathbf{5 0} \\
(41.0)\end{array}$ & $\begin{array}{c}\mathbf{2 7} \\
(22.1)\end{array}$ & $\begin{array}{c}\mathbf{6} \\
(4.9)\end{array}$ & $\begin{array}{c}19 \\
(43.2)\end{array}$ & $\begin{array}{c}18 \\
(40.9)\end{array}$ & $\begin{array}{c}7 \\
(15.9)\end{array}$ & $\begin{array}{c}\mathbf{0} \\
(0.0)\end{array}$ \\
\hline 9. & The tool did work as expected & $\begin{array}{c}\mathbf{2 2} \\
(18.0)\end{array}$ & $\begin{array}{c}\mathbf{1 2} \\
(9.8)\end{array}$ & $\begin{array}{c}\mathbf{8 6} \\
(70.5)\end{array}$ & $\begin{array}{c}\mathbf{2} \\
(1.6)\end{array}$ & $\begin{array}{c}\mathbf{6} \\
(13.6)\end{array}$ & $\begin{array}{c}\mathbf{6} \\
(13.6)\end{array}$ & $\begin{array}{c}\mathbf{3 1} \\
(70.5)\end{array}$ & $\begin{array}{c}\mathbf{1} \\
(2.3)\end{array}$ \\
\hline
\end{tabular}

Note. Frequency of responses is in boldface; percentage is italicized and parenthesized. 
Table B5: Students' perceptions of collaborative writing according to interest in digital tools

\begin{tabular}{|c|c|c|c|c|c|c|c|c|c|}
\hline \multirow{2}{*}{\multicolumn{2}{|c|}{ Statement }} & \multicolumn{4}{|c|}{$\begin{array}{c}\text { Medium, low, very low, } \\
\text { Don't know } \\
(n=55)\end{array}$} & \multicolumn{4}{|c|}{$\begin{array}{l}\text { High or very high } \\
(n=111) \\
\end{array}$} \\
\hline & & $\begin{array}{l}\text { Strongly } \\
\text { agree/ } \\
\text { Agree }\end{array}$ & $\begin{array}{l}\text { Neither } \\
\text { agree } \\
\text { nor } \\
\text { disagree }\end{array}$ & $\begin{array}{l}\text { Strongly } \\
\text { disagree/ } \\
\text { Disagree }\end{array}$ & $\begin{array}{l}\text { Don't } \\
\text { know }\end{array}$ & $\begin{array}{l}\text { Strongly } \\
\text { agree/ } \\
\text { Agree }\end{array}$ & $\begin{array}{l}\text { Neither } \\
\text { agree } \\
\text { nor } \\
\text { disagree }\end{array}$ & $\begin{array}{l}\text { Strongly } \\
\text { disagree/ } \\
\text { Disagree }\end{array}$ & $\begin{array}{l}\text { Don’t } \\
\text { know }\end{array}$ \\
\hline 1. & $\begin{array}{l}\text { It was easy to use the tool in } \\
\text { group work }\end{array}$ & $\begin{array}{c}19 \\
(34.5)\end{array}$ & $\begin{array}{c}\mathbf{1 4} \\
(25.5)\end{array}$ & $\begin{array}{c}\mathbf{2 2} \\
(40.0)\end{array}$ & $\begin{array}{c}\mathbf{0} \\
(0.0)\end{array}$ & $\begin{array}{c}\mathbf{4 5} \\
(40.5)\end{array}$ & $\begin{array}{c}\mathbf{4 0} \\
(36.0)\end{array}$ & $\begin{array}{c}\mathbf{2 6} \\
(23.4)\end{array}$ & $\begin{array}{c}\mathbf{0} \\
(0.0)\end{array}$ \\
\hline 2. & $\begin{array}{l}\text { It was effective to use the tool } \\
\text { in group work }\end{array}$ & $\begin{array}{c}\mathbf{1 0} \\
(18.2)\end{array}$ & $\begin{array}{c}22 \\
(40.0)\end{array}$ & $\begin{array}{c}\mathbf{2 3} \\
(41.8)\end{array}$ & $\begin{array}{c}\mathbf{0} \\
(0.0)\end{array}$ & $\begin{array}{c}34 \\
(30.6)\end{array}$ & $\begin{array}{c}\mathbf{3 8} \\
(34.2)\end{array}$ & $\begin{array}{c}\mathbf{3 8} \\
(34.2)\end{array}$ & $\begin{array}{c}1 \\
(0.9)\end{array}$ \\
\hline 3. & $\begin{array}{l}\text { The tool was easier to use than } \\
\text { traditional tools such as MS } \\
\text { Word }\end{array}$ & $\begin{array}{c}15 \\
(27.3)\end{array}$ & $\begin{array}{c}\mathbf{1 8} \\
(32.7)\end{array}$ & $\begin{array}{c}\mathbf{2 2} \\
(40.0)\end{array}$ & $\begin{array}{c}\mathbf{0} \\
(0.0)\end{array}$ & $\begin{array}{c}39 \\
(35.1)\end{array}$ & $\begin{array}{c}34 \\
(30.6)\end{array}$ & $\begin{array}{c}37 \\
(33.3)\end{array}$ & $\begin{array}{c}1 \\
(0.9)\end{array}$ \\
\hline 4. & $\begin{array}{l}\text { I liked to comment and edit } \\
\text { others contributions to group } \\
\text { work }\end{array}$ & $\begin{array}{c}\mathbf{1 3} \\
(23.6)\end{array}$ & $\begin{array}{c}\mathbf{1 6} \\
(29.1)\end{array}$ & $\begin{array}{c}\mathbf{2 2} \\
(40.0)\end{array}$ & $\begin{array}{c}\mathbf{4} \\
(7.3)\end{array}$ & $\begin{array}{c}39 \\
(35.1)\end{array}$ & $\begin{array}{c}\mathbf{4 3} \\
(38.7)\end{array}$ & $\begin{array}{c}\mathbf{2 5} \\
(22.5)\end{array}$ & $\begin{array}{c}\mathbf{4} \\
(3.6)\end{array}$ \\
\hline 5. & $\begin{array}{l}\text { I liked that other students } \\
\text { comment and edit my own } \\
\text { work in the group }\end{array}$ & $\begin{array}{c}\mathbf{2 1} \\
(38.2)\end{array}$ & $\begin{array}{c}17 \\
(30.9)\end{array}$ & $\begin{array}{c}\mathbf{1 2} \\
(21.8)\end{array}$ & $\begin{array}{c}\mathbf{5} \\
(9.1)\end{array}$ & $\begin{array}{c}\mathbf{5 8} \\
(52.3)\end{array}$ & $\begin{array}{c}\mathbf{4 2} \\
(37.8)\end{array}$ & $\begin{array}{c}\mathbf{8} \\
(7.2)\end{array}$ & $\begin{array}{c}3 \\
(2.7)\end{array}$ \\
\hline 6. & $\begin{array}{l}\text { The quality of collaboration in } \\
\text { the group increased with the } \\
\text { use of the tool }\end{array}$ & $\begin{array}{c}\mathbf{5} \\
(9.1)\end{array}$ & $\begin{array}{c}\mathbf{1 5} \\
(27.3)\end{array}$ & $\begin{array}{c}\mathbf{3 2} \\
(58.2)\end{array}$ & $\begin{array}{c}\mathbf{3} \\
(5.5)\end{array}$ & $\begin{array}{c}\mathbf{2 1} \\
(18.9)\end{array}$ & $\begin{array}{c}39 \\
(35.1)\end{array}$ & $\begin{array}{c}\mathbf{4 7} \\
(42.3)\end{array}$ & $\begin{array}{c}\mathbf{4} \\
(3.6)\end{array}$ \\
\hline 7. & $\begin{array}{l}\text { The tool motivated me to col- } \\
\text { laborate with the students in the } \\
\text { group }\end{array}$ & $\begin{array}{c}\mathbf{4} \\
(7.3)\end{array}$ & $\begin{array}{c}17 \\
(30.9)\end{array}$ & $\begin{array}{c}33 \\
(60.0)\end{array}$ & $\begin{array}{c}\mathbf{1} \\
(1.8)\end{array}$ & $\begin{array}{c}\mathbf{1 9} \\
(17.1)\end{array}$ & $\begin{array}{c}\mathbf{4 5} \\
(40.5)\end{array}$ & $\begin{array}{c}\mathbf{4 6} \\
(41.4)\end{array}$ & $\begin{array}{c}\mathbf{1} \\
(0.9)\end{array}$ \\
\hline 8. & $\begin{array}{l}\text { It was instructive to edit and } \\
\text { comment others contributions } \\
\text { to group work }\end{array}$ & $\begin{array}{c}\mathbf{1 4} \\
(25.5)\end{array}$ & $\begin{array}{c}22 \\
(40.0)\end{array}$ & $\begin{array}{c}17 \\
(30.9)\end{array}$ & $\begin{array}{c}\mathbf{2} \\
(3.6)\end{array}$ & $\begin{array}{c}\mathbf{4 4} \\
(39.6)\end{array}$ & $\begin{array}{c}\mathbf{4 6} \\
(41.4)\end{array}$ & $\begin{array}{c}\mathbf{1 7} \\
(15.3)\end{array}$ & $\begin{array}{c}\mathbf{4} \\
(3.6)\end{array}$ \\
\hline 9. & The tool did work as expected & $\begin{array}{c}\mathbf{6} \\
(10.9)\end{array}$ & $\begin{array}{c}\mathbf{5} \\
(9.1)\end{array}$ & $\begin{array}{c}\mathbf{4 3} \\
(78.2)\end{array}$ & $\begin{array}{c}\mathbf{1} \\
(1.8)\end{array}$ & $\begin{array}{c}\mathbf{2 2} \\
(19.8)\end{array}$ & $\begin{array}{c}\mathbf{1 3} \\
(11.7)\end{array}$ & $\begin{array}{c}\mathbf{7 4} \\
(66.7)\end{array}$ & $\begin{array}{c}\mathbf{2} \\
(1.8)\end{array}$ \\
\hline
\end{tabular}

Note. Frequency of responses is in boldface; percentage is italicized and parenthesized. 
Table 6: Students' perceptions of collaborative writing according to how important they assume digital tools to be in their future work as a teacher

\begin{tabular}{|c|c|c|c|c|c|c|c|c|c|}
\hline \multirow{2}{*}{\multicolumn{2}{|c|}{ Statement }} & \multicolumn{4}{|c|}{$\begin{array}{c}\text { Medium, low, very low, } \\
\text { Don't know } \\
(n=51)\end{array}$} & \multicolumn{4}{|c|}{$\begin{array}{l}\text { High or very high } \\
(n=115) \\
\end{array}$} \\
\hline & & $\begin{array}{l}\text { Strongly } \\
\text { agree/ } \\
\text { Agree }\end{array}$ & $\begin{array}{l}\text { Neither } \\
\text { agree } \\
\text { nor } \\
\text { disagree }\end{array}$ & $\begin{array}{l}\text { Strongly } \\
\text { disagree/ } \\
\text { Disagree }\end{array}$ & $\begin{array}{l}\text { Don't } \\
\text { know }\end{array}$ & $\begin{array}{l}\text { Strongly } \\
\text { agree/ } \\
\text { Agree }\end{array}$ & $\begin{array}{l}\text { Neither } \\
\text { agree } \\
\text { nor } \\
\text { disagree }\end{array}$ & $\begin{array}{l}\text { Strongly } \\
\text { disagree/ } \\
\text { Disagree }\end{array}$ & $\begin{array}{l}\text { Don't } \\
\text { know }\end{array}$ \\
\hline 1. & $\begin{array}{l}\text { It was easy to use the tool in } \\
\text { group work }\end{array}$ & $\begin{array}{c}\mathbf{2 0} \\
(39.2)\end{array}$ & $\begin{array}{c}13 \\
(25.5)\end{array}$ & $\begin{array}{c}\mathbf{1 8} \\
(35.3)\end{array}$ & $\begin{array}{c}\mathbf{0} \\
(0.0)\end{array}$ & $\begin{array}{c}\mathbf{4 4} \\
(38.3)\end{array}$ & $\begin{array}{c}\mathbf{4 1} \\
(35.7)\end{array}$ & $\begin{array}{c}30 \\
(26.1)\end{array}$ & $\begin{array}{c}\mathbf{0} \\
(0.0)\end{array}$ \\
\hline 2. & $\begin{array}{l}\text { It was effective to use the tool } \\
\text { in group work }\end{array}$ & $\begin{array}{c}14 \\
(27.5)\end{array}$ & $\begin{array}{c}\mathbf{2 1} \\
(41.2)\end{array}$ & $\begin{array}{c}\mathbf{1 6} \\
(31.4)\end{array}$ & $\begin{array}{c}\mathbf{0} \\
(0.0)\end{array}$ & $\begin{array}{c}\mathbf{3 0} \\
(26.1)\end{array}$ & $\begin{array}{c}39 \\
(33.9)\end{array}$ & $\begin{array}{c}\mathbf{4 5} \\
(39.1)\end{array}$ & $\begin{array}{c}1 \\
(0.9)\end{array}$ \\
\hline 3. & $\begin{array}{l}\text { The tool was easier to use than } \\
\text { traditional tools such as MS } \\
\text { Word }\end{array}$ & $\begin{array}{c}17 \\
(33.3)\end{array}$ & $\begin{array}{c}13 \\
(25.5)\end{array}$ & $\begin{array}{c}\mathbf{2 1} \\
(41.2)\end{array}$ & $\begin{array}{c}\mathbf{0} \\
(0.0)\end{array}$ & $\begin{array}{c}37 \\
(32.2)\end{array}$ & $\begin{array}{c}39 \\
(33.9)\end{array}$ & $\begin{array}{c}\mathbf{3 8} \\
(33.0)\end{array}$ & $\begin{array}{c}1 \\
(0.9)\end{array}$ \\
\hline 4. & $\begin{array}{l}\text { I liked to comment and edit } \\
\text { others contributions to group } \\
\text { work }\end{array}$ & $\begin{array}{c}\mathbf{1 2} \\
(23.5)\end{array}$ & $\begin{array}{c}\mathbf{2 0} \\
(39.2)\end{array}$ & $\begin{array}{c}17 \\
(33.3)\end{array}$ & $\begin{array}{c}\mathbf{2} \\
(3.9)\end{array}$ & $\begin{array}{c}\mathbf{4 0} \\
(34.8)\end{array}$ & $\begin{array}{c}39 \\
(33.9)\end{array}$ & $\begin{array}{c}\mathbf{3 0} \\
(26.1)\end{array}$ & $\begin{array}{c}\mathbf{6} \\
(5.2)\end{array}$ \\
\hline 5. & $\begin{array}{l}\text { I liked that other students } \\
\text { comment and edit my own } \\
\text { work in the group }\end{array}$ & $\begin{array}{c}\mathbf{1 5} \\
(29.4)\end{array}$ & $\begin{array}{c}\mathbf{2 4} \\
(47.1)\end{array}$ & $\begin{array}{c}9 \\
(17.6)\end{array}$ & $\begin{array}{c}3 \\
(5.9)\end{array}$ & $\begin{array}{c}\mathbf{6 4} \\
(55.7)\end{array}$ & $\begin{array}{c}\mathbf{3 5} \\
(30.4)\end{array}$ & $\begin{array}{c}11 \\
(9.6)\end{array}$ & $\begin{array}{c}\mathbf{5} \\
(4.3)\end{array}$ \\
\hline 6. & $\begin{array}{l}\text { The quality of collaboration in } \\
\text { the group increased with the } \\
\text { use of the tool }\end{array}$ & $\begin{array}{c}\mathbf{5} \\
(9.8)\end{array}$ & $\begin{array}{c}17 \\
(33.3)\end{array}$ & $\begin{array}{c}\mathbf{2 6} \\
(51.0)\end{array}$ & $\begin{array}{c}\mathbf{3} \\
(5.9)\end{array}$ & $\begin{array}{c}\mathbf{2 1} \\
(18.3)\end{array}$ & $\begin{array}{c}37 \\
(32.2)\end{array}$ & $\begin{array}{c}\mathbf{5 3} \\
(46.1)\end{array}$ & $\begin{array}{c}\mathbf{4} \\
(3.5)\end{array}$ \\
\hline 7. & $\begin{array}{l}\text { The tool motivated me to col- } \\
\text { laborate with the students in the } \\
\text { group }\end{array}$ & $\mathbf{6}$ & $\begin{array}{c}15 \\
(29.4)\end{array}$ & $\begin{array}{c}29 \\
(56.9)\end{array}$ & $\begin{array}{c}\mathbf{1} \\
(2.0)\end{array}$ & $\begin{array}{c}17 \\
(14.8)\end{array}$ & $\begin{array}{c}\mathbf{4 7} \\
(40.9)\end{array}$ & $\begin{array}{c}\mathbf{5 0} \\
(43.5)\end{array}$ & $\begin{array}{c}\mathbf{1} \\
(0.9)\end{array}$ \\
\hline 8. & $\begin{array}{l}\text { It was instructive to edit and } \\
\text { comment others contributions } \\
\text { to group work }\end{array}$ & $\begin{array}{c}\mathbf{1 3} \\
(25.5)\end{array}$ & $\begin{array}{c}\mathbf{2 3} \\
(45.1)\end{array}$ & $\begin{array}{c}15 \\
(29.4)\end{array}$ & $\begin{array}{c}\mathbf{0} \\
(0.0)\end{array}$ & $\begin{array}{c}\mathbf{4 5} \\
(39.1)\end{array}$ & $\begin{array}{c}\mathbf{4 5} \\
(39.1)\end{array}$ & $\begin{array}{c}19 \\
(16.5)\end{array}$ & $\begin{array}{c}\mathbf{6} \\
(5.2)\end{array}$ \\
\hline 9. & The tool did work as expected & $\begin{array}{c}\mathbf{6} \\
(11.8)\end{array}$ & $\begin{array}{c}7 \\
(13.7)\end{array}$ & $\begin{array}{c}37 \\
(72.5)\end{array}$ & $\begin{array}{c}\mathbf{1} \\
(2.0)\end{array}$ & $\begin{array}{c}\mathbf{2 2} \\
(19.1)\end{array}$ & $\begin{array}{c}11 \\
(9.6)\end{array}$ & $\begin{array}{c}\mathbf{8 0} \\
(69.6)\end{array}$ & $\begin{array}{c}\mathbf{2} \\
(1.7)\end{array}$ \\
\hline
\end{tabular}

Note. Frequency of responses is in boldface; percentage is italicized and parenthesized. 
Table B7: Students' perceptions of collaborative writing in different educational settings

\begin{tabular}{|c|c|c|c|c|c|c|c|c|c|}
\hline \multirow{2}{*}{\multicolumn{2}{|c|}{ Statement }} & \multicolumn{4}{|c|}{$\begin{array}{c}\mathrm{C} 1 \\
(n=154)\end{array}$} & \multicolumn{4}{|c|}{$\begin{array}{c}\mathrm{C} 2 \\
(n=12)\end{array}$} \\
\hline & & $\begin{array}{l}\text { Strongly } \\
\text { agree/ } \\
\text { Agree }\end{array}$ & $\begin{array}{c}\text { Neither } \\
\text { agree } \\
\text { nor } \\
\text { disagree }\end{array}$ & $\begin{array}{l}\text { Strongly } \\
\text { disagree/ } \\
\text { Disagree }\end{array}$ & $\begin{array}{l}\text { Don’t } \\
\text { know }\end{array}$ & $\begin{array}{l}\text { Strongly } \\
\text { agree/ } \\
\text { Agree }\end{array}$ & $\begin{array}{l}\text { Neither } \\
\text { agree } \\
\text { nor } \\
\text { disagree }\end{array}$ & $\begin{array}{l}\text { Strongly } \\
\text { disagree/ } \\
\text { Disagree }\end{array}$ & $\begin{array}{l}\text { Don't } \\
\text { know }\end{array}$ \\
\hline 1 . & $\begin{array}{l}\text { It was easy to use the tool in } \\
\text { group work }\end{array}$ & $\begin{array}{c}61 \\
(39.6)\end{array}$ & $\begin{array}{c}47 \\
(30.5)\end{array}$ & $\begin{array}{c}\mathbf{4 6} \\
(29.9)\end{array}$ & $\begin{array}{c}\mathbf{0} \\
(0.0)\end{array}$ & $\begin{array}{c}3 \\
(25.0)\end{array}$ & $\begin{array}{c}7 \\
(58.3)\end{array}$ & $\begin{array}{c}2 \\
(16.7)\end{array}$ & $\begin{array}{c}\mathbf{0} \\
(0.0)\end{array}$ \\
\hline 2. & $\begin{array}{l}\text { It was effective to use the tool } \\
\text { in group work }\end{array}$ & $\begin{array}{c}43 \\
(27.9)\end{array}$ & $\begin{array}{c}\mathbf{5 8} \\
(37.7)\end{array}$ & $\begin{array}{c}\mathbf{5 2} \\
(33.8)\end{array}$ & $\begin{array}{c}1 \\
(0.6)\end{array}$ & $\begin{array}{c}1 \\
(8.3)\end{array}$ & $\begin{array}{c}2 \\
(16.7)\end{array}$ & $\begin{array}{c}9 \\
(75.0)\end{array}$ & $\begin{array}{c}\mathbf{0} \\
(0.0)\end{array}$ \\
\hline 3. & $\begin{array}{l}\text { The tool was easier to use than } \\
\text { traditional tools such as MS } \\
\text { Word }\end{array}$ & $\begin{array}{c}\mathbf{5 1} \\
(33.1)\end{array}$ & $\begin{array}{c}49 \\
(31.8)\end{array}$ & $\begin{array}{c}\mathbf{5 3} \\
(34.4)\end{array}$ & $\begin{array}{c}1 \\
(0.6)\end{array}$ & $\begin{array}{c}3 \\
(25.0)\end{array}$ & $\begin{array}{c}3 \\
(25.0)\end{array}$ & $\begin{array}{c}6 \\
(50.0)\end{array}$ & $\begin{array}{c}\mathbf{0} \\
(0.0)\end{array}$ \\
\hline 4. & $\begin{array}{l}\text { I liked to comment and edit } \\
\text { others contributions to group } \\
\text { work }\end{array}$ & $\begin{array}{c}49 \\
(31.8)\end{array}$ & $\begin{array}{c}\mathbf{5 5} \\
(35.7)\end{array}$ & $\begin{array}{c}\mathbf{4 3} \\
(27.9)\end{array}$ & $\begin{array}{c}7 \\
(4.5)\end{array}$ & $\begin{array}{c}3 \\
(25.0)\end{array}$ & $\begin{array}{c}\mathbf{4} \\
(33.3)\end{array}$ & $\begin{array}{c}\mathbf{4} \\
(33.3)\end{array}$ & $\begin{array}{c}1 \\
(8.3)\end{array}$ \\
\hline 5 . & $\begin{array}{l}\text { I liked that other students } \\
\text { comment and edit my own } \\
\text { work in the group }\end{array}$ & $\begin{array}{c}76 \\
(49.4)\end{array}$ & $\begin{array}{c}\mathbf{5 2} \\
(33.8)\end{array}$ & $\begin{array}{c}\mathbf{1 8} \\
(11.7)\end{array}$ & $\begin{array}{c}8 \\
(5.2)\end{array}$ & $\begin{array}{c}\mathbf{3} \\
(25.0)\end{array}$ & $\begin{array}{c}7 \\
(58.3)\end{array}$ & $\begin{array}{c}\mathbf{2} \\
(16.7)\end{array}$ & $\begin{array}{c}\mathbf{0} \\
(0.0)\end{array}$ \\
\hline 6. & $\begin{array}{l}\text { The quality of collaboration in } \\
\text { the group increased with the } \\
\text { use of the tool }\end{array}$ & $\begin{array}{c}24 \\
(15.6)\end{array}$ & $\begin{array}{c}\mathbf{5 3} \\
(34.4)\end{array}$ & $\begin{array}{c}71 \\
(46.1)\end{array}$ & $\begin{array}{c}\mathbf{6} \\
(3.9)\end{array}$ & $\begin{array}{c}\mathbf{2} \\
(16.7)\end{array}$ & $\begin{array}{c}1 \\
(8.3)\end{array}$ & $\begin{array}{c}8 \\
(66.7)\end{array}$ & $\begin{array}{c}1 \\
(8.3)\end{array}$ \\
\hline 7. & $\begin{array}{l}\text { The tool motivated me to col- } \\
\text { laborate with the students in the } \\
\text { group }\end{array}$ & $\begin{array}{c}22 \\
(14.3)\end{array}$ & $\begin{array}{c}\mathbf{5 9} \\
(38.3)\end{array}$ & $\begin{array}{c}71 \\
(46.1)\end{array}$ & $\begin{array}{c}2 \\
(1.3)\end{array}$ & $\begin{array}{c}1 \\
(8.3)\end{array}$ & $\begin{array}{c}\mathbf{3} \\
(25.0)\end{array}$ & $\begin{array}{c}8 \\
(4.8)\end{array}$ & $\begin{array}{c}\mathbf{0} \\
(0.0)\end{array}$ \\
\hline 8 . & $\begin{array}{l}\text { It was instructive to edit and } \\
\text { comment others contributions } \\
\text { to group work }\end{array}$ & $\begin{array}{c}\mathbf{5 5} \\
(35.7)\end{array}$ & $\begin{array}{c}61 \\
(39.6)\end{array}$ & $\begin{array}{c}32 \\
(20.8)\end{array}$ & $\begin{array}{c}\mathbf{6} \\
(3.9)\end{array}$ & $\begin{array}{c}\mathbf{3} \\
(25.0)\end{array}$ & $\begin{array}{c}7 \\
(58.3)\end{array}$ & $\begin{array}{c}\mathbf{2} \\
(16.7)\end{array}$ & $\begin{array}{c}\mathbf{0} \\
(0.0)\end{array}$ \\
\hline 9. & The tool did work as expected & $\begin{array}{c}\mathbf{2 5} \\
(16.2)\end{array}$ & $\begin{array}{c}16 \\
(10.4)\end{array}$ & $\begin{array}{c}111 \\
(72.1)\end{array}$ & $\begin{array}{c}2 \\
(1.3)\end{array}$ & $\begin{array}{c}3 \\
(25.0)\end{array}$ & $\begin{array}{c}2 \\
(16.7)\end{array}$ & $\begin{array}{c}6 \\
(50.0)\end{array}$ & $\begin{array}{c}1 \\
(8.3)\end{array}$ \\
\hline
\end{tabular}

Note. Frequency of responses is in boldface; percentage is italicized and parenthesized. Responses are related to two campuses with different educational settings: $\mathrm{C} 1=$ main campus; $\mathrm{C} 2=$ satellite campus 
Table B8: Students' perceptions of collaborative writing according to tool used

\begin{tabular}{|c|c|c|c|c|c|c|c|c|c|}
\hline \multirow{2}{*}{\multicolumn{2}{|c|}{ Statement }} & \multicolumn{4}{|c|}{$\begin{array}{l}\text { EtherPad } \\
(n=132) \\
\end{array}$} & \multicolumn{4}{|c|}{$\begin{array}{l}\text { Google Docs } \\
(n=34)\end{array}$} \\
\hline & & $\begin{array}{c}\text { Strongly } \\
\text { agree/ } \\
\text { Agree }\end{array}$ & $\begin{array}{l}\text { Neither } \\
\text { agree } \\
\text { nor } \\
\text { disagree }\end{array}$ & $\begin{array}{l}\text { Strongly } \\
\text { disagree/ } \\
\text { Disagree }\end{array}$ & $\begin{array}{l}\text { Don't } \\
\text { know }\end{array}$ & $\begin{array}{l}\text { Strongly } \\
\text { agree/ } \\
\text { Agree }\end{array}$ & $\begin{array}{l}\text { Neither } \\
\text { agree } \\
\text { nor } \\
\text { disagree }\end{array}$ & $\begin{array}{l}\text { Strongly } \\
\text { disagree/ } \\
\text { Disagree }\end{array}$ & $\begin{array}{l}\text { Don't } \\
\text { know }\end{array}$ \\
\hline 1. & $\begin{array}{l}\text { It was easy to use the tool in } \\
\text { group work }\end{array}$ & $\begin{array}{c}\mathbf{4 7} \\
(35.6)\end{array}$ & $\begin{array}{c}\mathbf{4 2} \\
(31.8)\end{array}$ & $\begin{array}{c}\mathbf{4 3} \\
(32.6)\end{array}$ & $\begin{array}{c}\mathbf{0} \\
(0.0)\end{array}$ & $\begin{array}{c}17 \\
(50.0)\end{array}$ & $\begin{array}{c}\mathbf{1 2} \\
(35.3)\end{array}$ & $\begin{array}{c}\mathbf{5} \\
(14.7)\end{array}$ & $\begin{array}{c}\mathbf{0} \\
(0.0)\end{array}$ \\
\hline 2. & $\begin{array}{l}\text { It was effective to use the tool } \\
\text { in group work }\end{array}$ & $\begin{array}{c}\mathbf{3 0} \\
(22.7)\end{array}$ & $\begin{array}{c}\mathbf{5 0} \\
(37.9)\end{array}$ & $\begin{array}{c}\mathbf{5 1} \\
(38.6)\end{array}$ & $\begin{array}{c}1 \\
(0.8)\end{array}$ & $\begin{array}{c}14 \\
(41.2)\end{array}$ & $\begin{array}{c}\mathbf{1 0} \\
(29.4)\end{array}$ & $\begin{array}{c}\mathbf{1 0} \\
(29.4)\end{array}$ & $\begin{array}{c}\mathbf{0} \\
(0.0)\end{array}$ \\
\hline 3. & $\begin{array}{l}\text { The tool was easier to use than } \\
\text { traditional tools such as MS } \\
\text { Word }\end{array}$ & $\begin{array}{c}39 \\
(29.5)\end{array}$ & $\begin{array}{c}\mathbf{4 3} \\
(32.6)\end{array}$ & $\begin{array}{c}49 \\
(37.1)\end{array}$ & $\begin{array}{c}\mathbf{1} \\
(0.8)\end{array}$ & $\begin{array}{c}\mathbf{1 5} \\
(44.1)\end{array}$ & $\begin{array}{c}9 \\
(26.5)\end{array}$ & $\begin{array}{c}\mathbf{1 0} \\
(29.4)\end{array}$ & $\begin{array}{c}\mathbf{0} \\
(0.0)\end{array}$ \\
\hline 4. & $\begin{array}{l}\text { I liked to comment and edit } \\
\text { others contributions to group } \\
\text { work }\end{array}$ & $\begin{array}{c}\mathbf{4 3} \\
(32.6)\end{array}$ & $\begin{array}{c}\mathbf{4 1} \\
(31.1)\end{array}$ & $\begin{array}{c}\mathbf{4 0} \\
(30.3)\end{array}$ & $\begin{array}{c}\mathbf{8} \\
(6.1)\end{array}$ & $\begin{array}{c}9 \\
(26.5)\end{array}$ & $\begin{array}{c}\mathbf{1 8} \\
(52.9)\end{array}$ & $\begin{array}{c}7 \\
(20.6)\end{array}$ & $\begin{array}{c}\mathbf{0} \\
(0.0)\end{array}$ \\
\hline 5. & $\begin{array}{l}\text { I liked that other students } \\
\text { comment and edit my own } \\
\text { work in the group }\end{array}$ & $\begin{array}{c}\mathbf{5 8} \\
(43.9)\end{array}$ & $\begin{array}{c}48 \\
(36.4)\end{array}$ & $\begin{array}{c}19 \\
(14.4)\end{array}$ & $\begin{array}{c}7 \\
(5.3)\end{array}$ & $\begin{array}{c}\mathbf{2 1} \\
(61.8)\end{array}$ & $\begin{array}{c}11 \\
(32.4)\end{array}$ & $\begin{array}{c}1 \\
(2.9)\end{array}$ & $\begin{array}{c}1 \\
(2.9)\end{array}$ \\
\hline 6. & $\begin{array}{l}\text { The quality of collaboration in } \\
\text { the group increased with the } \\
\text { use of the tool }\end{array}$ & $\begin{array}{c}\mathbf{1 8} \\
(13.6)\end{array}$ & $\begin{array}{c}\mathbf{4 5} \\
(34.1)\end{array}$ & $\begin{array}{c}\mathbf{6 4} \\
(48.5)\end{array}$ & $\begin{array}{c}\mathbf{5} \\
(3.8)\end{array}$ & $\begin{array}{c}\mathbf{8} \\
(23.5)\end{array}$ & $\begin{array}{c}9 \\
(26.5)\end{array}$ & $\begin{array}{c}\mathbf{1 5} \\
(44.1)\end{array}$ & $\begin{array}{c}\mathbf{2} \\
(5.9)\end{array}$ \\
\hline 7. & $\begin{array}{l}\text { The tool motivated me to col- } \\
\text { laborate with the students in the } \\
\text { group }\end{array}$ & $\begin{array}{c}\mathbf{2 1} \\
(15.9)\end{array}$ & $\begin{array}{c}\mathbf{4 7} \\
(35.6)\end{array}$ & $\begin{array}{c}\mathbf{6 2} \\
(47.0)\end{array}$ & $\begin{array}{c}\mathbf{2} \\
(1.5)\end{array}$ & $\begin{array}{c}\mathbf{2} \\
(5.9)\end{array}$ & $\begin{array}{c}15 \\
(44.1)\end{array}$ & $\begin{array}{c}17 \\
(50.0)\end{array}$ & $\begin{array}{c}\mathbf{0} \\
(0.0)\end{array}$ \\
\hline 8. & $\begin{array}{l}\text { It was instructive to edit and } \\
\text { comment others contributions } \\
\text { to group work }\end{array}$ & $\begin{array}{c}\mathbf{4 6} \\
(34.8)\end{array}$ & $\begin{array}{c}\mathbf{5 1} \\
(38.6)\end{array}$ & $\begin{array}{c}\mathbf{3 0} \\
(22.7)\end{array}$ & $\begin{array}{c}\mathbf{5} \\
(3.8)\end{array}$ & $\begin{array}{c}12 \\
(35.3)\end{array}$ & $\begin{array}{c}17 \\
(50.0)\end{array}$ & $\begin{array}{c}\mathbf{4} \\
(11.8)\end{array}$ & $\begin{array}{c}\mathbf{1} \\
(2.9)\end{array}$ \\
\hline 9. & The tool did work as expected & $\begin{array}{c}14 \\
(10.6)\end{array}$ & $\begin{array}{c}13 \\
(9.8)\end{array}$ & $\begin{array}{c}103 \\
(78.0)\end{array}$ & $\begin{array}{c}\mathbf{2} \\
(1.5)\end{array}$ & $\begin{array}{c}\mathbf{1 4} \\
(41.2)\end{array}$ & $\begin{array}{c}\mathbf{5} \\
(14.7)\end{array}$ & $\begin{array}{c}14 \\
(41.2)\end{array}$ & $\begin{array}{c}\mathbf{1} \\
(2.9)\end{array}$ \\
\hline
\end{tabular}

Note. Frequency of responses is in boldface; percentage is italicized and parenthesized. 


\section{Biographies}

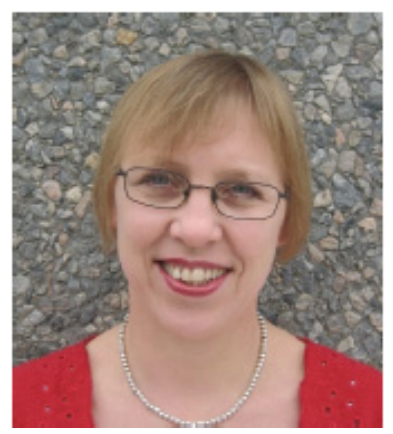

Cornelia Brodahl received the master degree in Mathematics from the University of Münster (Germany) in 1979. She joined University of Agder, Kristiansand (Norway) in 2001. She is currently an Associate Professor of ICT in Learning at the Faculty of Engineering and Science. She has been in the teaching profession since 1980 and worked as system analyst in industry in 1998-2001. Her research and teaching interests include ICT and learning, and Professional ICT Didactics. Main areas of expertise and interest are ICT supported learning, digital teaching aids, pedagogical Web design, and didactical animations in mathematics.

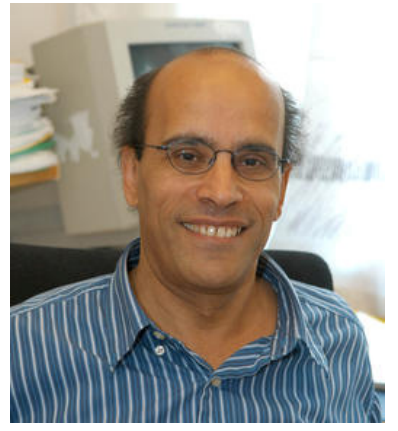

Said Hadjerrouit is a Full Professor of Informatics at the University of Agder. He holds a Ph.D. (1992) in Medical Expert Systems and Artificial Intelligence, and a Master (1985) in Software Engineering from the Technical University of Berlin (Germany). He has been working at the University of Agder since 1991. Hadjerrouit has teaching experience in informatics and society, philosophical and ethical issues of computing, object-oriented programming, Web engineering, software development, databases, didactics of informatics, ICT in mathematics education, and ICT-based learning. His current research focuses on software engineering education, didactics of informatics, ICT in mathematics education, e-Learning, technology-enhanced learning, Web-based learning resources, Web 2.0 technology and social software.

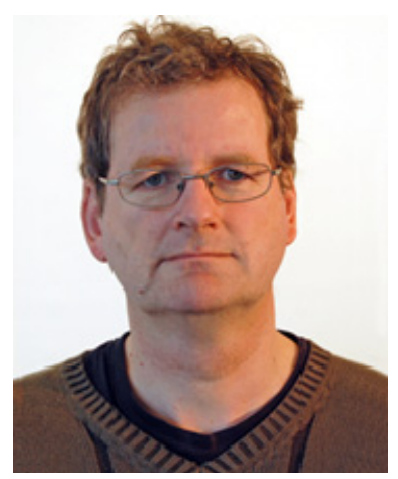

Nils Kristian Hansen received a master degree in electronics / computer science from The Norwegian Institute of Technology, Trondheim (Norway) 1987 and also holds an intermediate degree in Mathematics from the University of Agder, Kristiansand (Norway).

He joined the University of Agder in 2002, and is currently employed as a Chief Engineer at the Department of Technology and Science. He teaches Computer Science and Mathematics and provides computer support for teaching and research. Professional interests include software development and use of computers and technology in education. 